NASA Technical Memorandum 100945 AIAA-88-3149

\title{
Summary of Low-Speed Wind Tunnel Results of Several High-Speed Counterrotation Propeller Configurations
}

Christopher E. Hughes

National Aeronautics and Space Administration

Lewis Research Center

Cleveland, Ohio

and

John A. Gazzaniga

Sverdrup Technology, Inc.

NASA Lewis Research Center Group

Cleveland, Ohio

Prepared for the

24th Joint Propulsion Conference

cosponsored by the AIAA, ASME, SAE, and ASEE

Boston, Massachusetts, July 11-13, 1988 
AIAA-88-3149

Summary of Low-Speed Wind Tunnel Results of Several High-Speed Counterrotation Propeller Configurations Christopher E. Hughes, NASA Lewis Research Center, Cleveland, $\mathrm{OH}$; and Joinn A. Gazzaniga, Sverdrup Technology, Inc., NASA Lewis Research Center Group, Cleveland, $\mathrm{OH}$

\section{AIAA/ASME/SAE/ASEE 24th JOINT PROPULSION CONFERENCE JULY 11-13, 1988/Boston, Massachusetts}


SUMMARY OF LOW-SPEED WIND TUNNEL RESULTS OF SEVERAL HIGH-SPEED

COUNTERROTATION PROPELLER CONFIGURATIONS

\author{
Christopher E. Hughes \\ National Aeronautics and Space Administration \\ Lewis Research Center \\ Cleveland, Ohio 44135 \\ and \\ John A. Gazzaniga \\ Sverdrup Technology. Inc. \\ NASA Lewis Research Center Group \\ Cleveland, Ohio 44135
}

\begin{abstract}
SUMMARY
The low-speed aerodynamic performance characteristics of several advanced counterrotation pusher-propeller configurations with cruise design Mach numbers of 0.72 and 0.80 were investigated in the NASA Lewis Research Center 9- by 15-Foot Low Speed Wind Tunnel. The tests were conducted at Mach numbers representative of the take-off/landing flight regime. The investigation included: (1) the propeller performance characteristics over a range of blade angle settings and rotational speeds at a Mach number of 0.20 ; (2) the effect on the propeller performance of varying the axial rotor spacing and mismatching the power and rotational speeds on the propeller rotors; and (3) determining the reverse thrust performance characteristics at Mach numbers of $0.0,0.10,0.15$, and 0.20 .

The results of the investigation indicated that the overall low-speed performance of the counterrotation propeller configurations was reasonable. The maximum propeller net efficiency achieved was 52.4 percent by the F7/A7 11/9 propeller configuration at a take-off target operating point power loading parameter of 3.83 . The results also indicated that the performance of the propeller configurations was falrly insensitive to changes in axial rotor spacing and mismatched torque on the propeller rotors (resulting from mismatching the power and the rotational speed on the rotors) at a take-off point power loading parameter of 3.83. By decreasing the axial rotor spacing, the F7/A3 11/9 propeller configuration showed the largest difference in propeller performance with a 0.7 decrease in net efficiency and a 6.1 percent increase in torque ratio. By mismatching the power on the propeller rotors (by increasing the aft propeller rotor blade angles), the $F 7 / A 311 / 9$ configuration had the largest difference in performance with a 0.8 percent decrease in net efficiency and a 28.4 percent increase in torque ratio. By mismatching the rotor rotational speeds 14.8 percent (by reducing the aft rotor rotational speed by $1100 \mathrm{rpm}$ ), the increase in F7/A7 8/8 propeller net efficiency was 1.5 percent and a 56.8 percent decrease in torque ratio. At Mach number 0.20 and 95 percent of the propeller design speed, the reverse thrust results indicated that the F7/A7 8/8 configuration produced 60.4 percent of the take-off point net forward thrust ( $625 \mathrm{lb}$ of force). At Mach number 0.0 (static conditions) and 95 percent design speed, the same propeller configuration produced reverse thrust equal to 43.5 percent of the take-off net thrust.
\end{abstract}


The high efficiency advantage of advanced high-speed propellers has been demonstrated in high-speed scale model wind tunnel tests (ref. 1). An advanced turboprop propulsion system therefore offers the potential for high propulsive efficiency. Figure 1 is a comparison of the installed propulsive efficiency of several different types of propulsion systems over a range of cruise flight Mach numbers. As can be seen, the turboprop offers improved performance over the conventional turbofan at all flight speeds. At high flight Mach numbers, the advanced turboprop overcomes the deficiencies of the conventional turboprop system, such as compressibility effects. In addition, further improvements in high-speed performance are possible over the single-rotation advanced turboprop using even more novel technology approaches, such as a single-rotation propeller with swirl recovery vanes or an advanced high-speed counterrotating propeller. At lower flight speeds, the performance advantage of the turboprop over the turbofan is even larger.

A summary of several NASA and industry studies (ref. 2) to evaluate the potential of advanced high-speed turboprop propulsion is presented in figure 2 . The figure shows the potential block fuel savings of a turboprop propulsion system as a function of the trip stage length. As can be seen in the figure, large fuel savings are possible with the turboprop propulsion. system at all stage lengths, especially at the shorter operating ranges. Since the shorter stage lengths are climb and descent dominant, the lower flight velocities provide the turboprop with an even larger advantage over the turbofan than at cruise flight conditions. The more advanced turboprop propulsion system, like counterrotation, can achieve a further improvement in performance.

In support of the NASA Lewis Advanced Turboprop Program to establish the advanced turboprop technology base, an investigation of the low-speed characteristics of several advanced high-speed counterrotation propeller configurations was conducted in the NASA Lewis 9- by 15-Foot Low Speed Wind Tunnel. The counterrotation propellers were pusher-type designs incorporating a high number of blades, from 16 to 20 total, with very high power loadings. The investigation determined the aerodynamic and aeroacoustic propeller performance of the counterrotation propeller configurations in the take-off/landing flight regime, including reverse thrust. This paper presents a summary of the wind tunnel test aerodynamic performance results for several model counterrotation prope1ler configurations.

NOMENCLATURE

A area, $f t^{2}$

$A_{A} \quad$ propelier annulus area, $\mathrm{ft}^{2}$

AF blade activity factor, $6250 \int_{(r / R)_{h u b}}^{1.0}\left(b / D_{p r o p}\right)(r / R)^{3} d(r / R)$

$d A \quad$ elemental area, $\mathrm{ft}^{2}$

$d(r / R)$ elemental radius ratio 


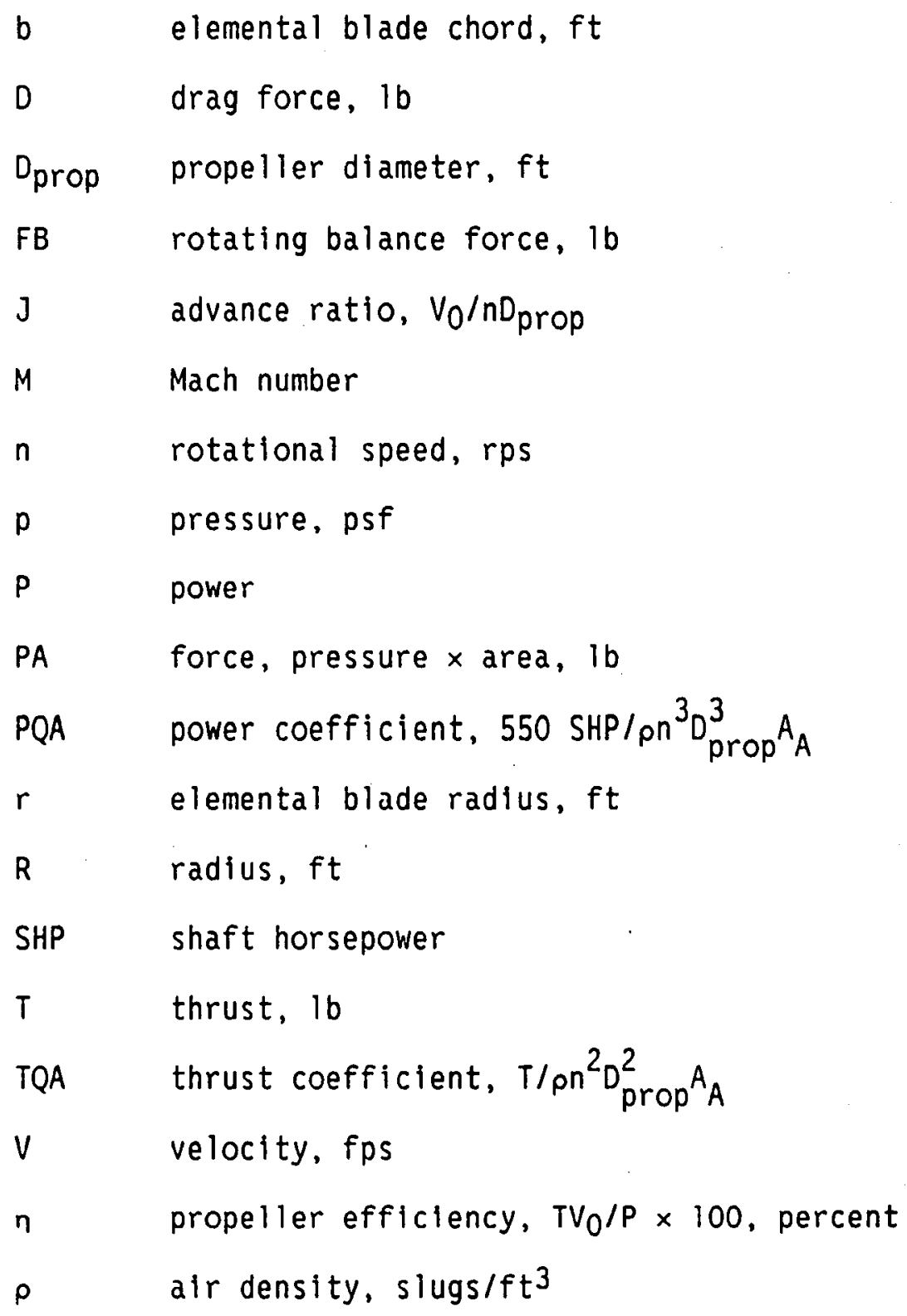

Subscripts

$\begin{array}{ll}\text { a } & \text { model nacelle afterbody } \\ \text { app } & \text { apparent } \\ f & \text { model nacelle forebode } \\ i & \text { internal } \\ \text { prop } & \text { propeller } \\ r & \text { rotor } \\ t & \text { tare } \\ 0 & \text { freestream condition }\end{array}$

3 


\title{
MODEL TEST PROGRAM
}

\author{
Wind Tunne 1
}

The model propeller test program was carried out in the NASA Lewis 9- by 15-Foot Low Speed Wind Tunnel (ref. 3). A schematic of the wind tunnel is shown in figure 3. The test section is located in the back leg of the 8- by 6-Foot Supersonic Wind Tunnel and is capable of speeds up to Mach number 0.23. The test section has slotted walls to minimize any model interaction with the tunnel walls and has been acoustically treated to allow propeller noise measurement.

\section{Propeller Test Rig}

The model Counterrotation Propeller Test Rig (CRP/PTR) used in the investigation was designed to simulate a counterrotating propulsion system in a pusher-propeller configuration. A photograph of the CRP/PTR installed in the NASA Lewis 9- by 15-Foot Low Speed Wind Tunnel is shown in figure 4 . The CRP/PTR was located near the middle of the test section axially, approximately $2 \mathrm{ft}$ from the test section centerline horizontally, and on the test section centerline vertically. A model support strut was used to mount the CRP/PTR to a rotating platform in the tunnel floor. The rotating platform allowed the CRP/PTR to yaw to simulate angle of attack. The large forward section of the CRP/PTR, known as the forebody, was designed to represent the faired-over inlet and nacelle sections of the core engine. The two rows of counterrotating propeller blades are mounted in the rotor hubs located behind the forebody. The hubs are contoured to provide area-ruling near the blade root section, thus reducing the high flow velocities between the propeller blades. The aft section of the CRP/PTR, behind the propeller blades and known as the afterbody, was designed to simulate the aft section of the engine nacelle and the core engine exhaust. The CRP/PTR turbine drive housing and model support strut are located at the back of the rig. The length of the CRP/PTR from the front of the forebody to the end of the turbine drive housing is approximately 120 in.

The CRP/PTR was capable of delivering up to 1350 total shaft horsepower with its two two-stage air-driven turbines (675 SHP each, using $450 \mathrm{psi}, 660^{\circ} \mathrm{R}$ high-pressure air) at a maximum rotational speed of $9000 \mathrm{rpm}$. Each turbine was used to supply power to one model propeller rotor hub via a drive shaft. From an aft-looking-forward position, the inner shaft and forward hub rotate in a counter-clockwise direction, while the outer shaft and aft hub rotate in a clockwise direction. A full description of the model propeller rig is given in reference 4 .

The CRP/PTR instrumentation for determining propeller performance consisted of several types. Loads generated by the propeller rotors during testing were measured using rotating force balances; each rotor hub was attached to the metric side of one of the force balances. The force balance measured the propeller rotor thrust and torque loads using strain-gauged flexure beams. The 
signals from the force balance were relayed through a telemetry unit to a monitoring station. Centrifugal stresses on the flexure beams were measured using strain gauges and force balance temperatures were measured using thermocouples attached to the balances. The force balance measurements were corrected using the centrifugal force and temperature measurements. Static pressures were measured on the CRP/PTR forebody and afterbody and in the rotor cavity areas using the Electronically Scanned Pressure (ESP) measurement system. The forebody and afterbody pressure instrumentation consisted of five rows of 13 pressure taps on the forebody and four rows of 12 pressure taps on the afterbody. Kulite pressure transducers were used to measure pressures in the cavities between the rotor hubs.

\section{Determination of Propeller Net Thrust}

The propeller net thrust is defined as the propulsive force of the propeller operating in the nacelle flowfield and adjusted for the change in the nacelle drag force due to the installed propeller (the propeller/nacelle interaction effect).

The reference, or tare, nacelle pressure and rotor drag forces are determined from model tare tests conducted with the propeller blades replaced by "dummy" blades that fill the blade holes in the rotors and are flush with the hub surface. Figure $5(a)$ provides a schematic of the tare model illustrating the drag forces components. The tare tests measure the pressures on the model forebody and afterbody and in the rotor cavity areas at the tunnel velocities where the propeller model will be operating. The tare rotor drag forces $\left(D_{r}, t\right.$ and $\left.D_{r 2},{ }\right)$ are obtained from the thrust forces measured by the hub force balances ( $F B_{1} t$ and $F B_{2}, t$ ). These thrust forces are corrected for the internal rotor cavity forces, determined by summation of the rotor cavity pressures acting on the upstream and downstream hub face surfaces on both propeller rotors $\left(\sum P A_{i}, 1 u, t, \sum P A_{i}, 1 d, t, \sum P A_{i}, 2 u, t\right.$, and $\left.\sum P A_{i}, 2 d, t\right)$. The tare forebody and afterbody pressure drag forces ( $D_{f}, t$ and $D_{a, t}$ ) are determined by integration of the static pressures measured over the nacelle surfaces. The model tare rotor drag forces are,

$$
\begin{aligned}
& -D_{r 1, t}=F B_{1, t}+\sum P A_{i, 1 u, t}-\sum P A_{i, 1 d, t} \\
& -D_{r 2, t}=F B_{2, t}+\sum P A_{i, 2 u, t}-\sum P A_{1,2 d, t}
\end{aligned}
$$

where

$P A_{i}=\left(p-P A_{0}\right)$

The model nacelle tare pressure drag forces are,

$$
\begin{aligned}
& D_{f, t}=\int\left(p_{f, t}-p_{0}\right) d A \\
& D_{a, t}=\int\left(p_{a, t}-p_{0}\right) d A
\end{aligned}
$$


The thrust forces measured by the hub rotating balances with the propeller blades installed and operating are the algebraic sum of tire propeller thrust, the external rotor drag forces and internal rotor cavity pressure forces. Figure $5(b)$ shows a schematic of the model with the propeller blades installed, illustrating the model forces with propellers operating. The uncorrected total propeller thrust is given by,

$T_{\text {prop, total }}=T_{\text {prop, } 1}+T_{\text {prop, } 2}$

$$
=\left(F B_{1}+\sum P A_{i, 1 u}-\sum P A_{i, 1 d}+D_{r l}\right)+\left(F B_{2}+\sum P A_{i, 2 u}-\sum P A_{i, 2 d}+D_{r 2}\right)
$$

A correction to the total propeller thrust for the difference in the rotor drag force with and without propeller blades (powered-minus-tare) is given by,

$$
\Delta D_{r, \text { total }}=\Delta D_{r 1}+\Delta D_{r 2}=D_{r 1}-D_{r 1, t}+D_{r 2}-D_{r 2, t}
$$

The total propeller apparent thrust is given by,

$$
T_{\text {app, total }}=T_{\text {prop, total }}-\Delta D_{r, \text { total }}
$$

or

$$
\begin{aligned}
T_{\text {app, total }}=\left(F B_{1}\right. & \left.+\sum P A_{i, 1 u}-\sum P A_{i, 1 d}+D_{r l, t}\right) \\
& +\left(F B_{2}+\sum P A_{i, 2 u}-\sum P A_{i, 2 d}+D_{r 2, t}\right)
\end{aligned}
$$

The total propeller net thrust is determined by subtracting the difference in the nacelle pressure drag forces with and without propeller blades (poweredminus-tare) from the total propeller apparent thrust,

$$
T_{\text {net, total }}=T_{\text {app, total }}-\left(\Delta D_{f}+\Delta D_{a}\right)
$$

where

$\Delta D_{f}=D_{f}-D_{f, t}$

$\Delta D_{a}=D_{a}-D_{a, t}$

The total propeller net thrust is, therefore, the thrust force measured by the rotating force balances, corrected for the powered internal rotor cavity forces, incremented by the tare rotor drag forces, and finally corrected for the difference between the nacelle pressure drag forces with and without propeller blades.

\section{Propeller Designs}

The design phllosophy used to generate the counterrotation propeller blades evolved from the philosophy used to design the first advanced high-speed 
single-rotation blade designs - enhance propeller performance and minimize propeller noise while maintaining a reasonable propeller size. The counterrotation propeller blades incorporated many of the design features necessary to achieve high propulsive efficiency at high flight Mach numbers. These design features included: (1) proper nacelle shaping and hub area-ruling to allow flow diffusion and reduce the blade inboard Mach number, thereby alleviate hub choking; (2) blade sweep, to reduce the effective blade Mach number near the propeller tip and minimize compressibility effects; (3) thin blades, to increase the blade drag rise Mach number; and (4) large blade chord lengths with large numbers of blades per rotor to obtain a high disk power loading (a higher total power loading than the single-rotation propeller designs) and thereby reduce the propeller diameter. A description of the method used to design the counterrotation propeller blades is given in reference 5 .

Table I provides a general summary of the individual model propeller blade design characteristics of the propeller blades tested. The "F" signifies forward rotor propeller blades, and the " $A$ " signifies aft rotor blades. The propeller blades were approximately $24.5 \mathrm{in}$. in diameter, except for the A3

blades. The reduced diameter and wider chord lengths of the A3 propeller blades was chosen to eliminate the interaction of the aft rotor propeller blades with the tip vortex from the forward rotor propeller blades while maintaining the amount of power absorbed by the aft rotor at the same rotor rotational speed. All the propeller blades were manufactured from composite materials (graphite and epoxy) with titanium spars. Photographs of the propeller blades used in the investigation are shown in figure 6 .

In table II, a summary of the design characteristics of the propeller configurations tested is given. Most of the investigation was conducted using the $11 / 9$ configuration; 11 blades in the forward rotor and 9 blades in the aft rotor. In this way, a higher disk power loading could be achieved which would allow a reduction in the propeller tip speed, and therefore the propeller noise, at the target operating condition. The F7/A7 propeller configuration was also tested in the $8 / 8$ configuration to obtain low speed data for comparison with F7/A7 11/9 performance. The Fl propeller blades, listed in table I, were only tested with the A7 blades (in lieu of the $F 7$ blades) during part of the investigation of the counterrotation propelier reverse thrust characteristics. Early in the reverse thrust testing, several of the F7 propeller blades suffered structural fallure, necessitating a switch to the geometricallysimilar Fl propeller blades. Since the Fl blades were not designed to be used with the $A 7$ blades, the F1/A7 configuration is not shown in table II.

\section{RESULTS AND DISCUSSION}

The low-speed characteristics of several counterrotation propeller configurations were investigated at a Mach number of 0.20 in the NASA Lewis 9- by 15-Foot Low Speed Wind Tunnel. Investigation of the reverse thrust characteristics of the F7/A7 $8 / 8$ propeller configuration was conducted at Mach numbers $0.0,0.10,0.15$, and 0.20 . A summary of the geometries tested for each propeller configuration is given in table III.

The propeller configurations were tested over a range of rotational speeds from windmill to the maximum rotational speed allowable; the maximum rotational speed was imposed by the structural limits of the propelier blades or, in some 
cases, the thrust load limits of the rotating force balances used. The prope1ler pitch, or blade, angles (defined at the three-quarter radius point on the propeller blade) were chosen to obtain data near the counterrotation propeller take-offllanding operating point. For several of the propeller configurations, more than one set of blade angles were chosen to vary the propeller power loading or the tip speed, or both, at the target operating points. During the investigation, the propeller configurations were typically tested with the propeller rotors at nearly equal, or matched, power and nearly matched rotational speed to obtain the target operating point propeller performance. For CRP/PTR operational considerations, matched rotor rotational speeds meant that the aft rotor rotational speed was set $50 \mathrm{rpm}$ higher than the forward rotor rotational speed at each propeller operating condition (the F7/A7 8/8 propeller configuration difference in rotor speeds was $100 \mathrm{rpm}$, to facilitate acoustic data acquisition).

Several variations in propeller geometry and operating conditions were introduced, and their effect on the propeller performance was determined. These variations included: (1) the axial spacing between the forward and aft rotors at equal rotor speeds; (2) mismatching the forward and aft rotor power, by varying the aft rotor power (by varying the aft rotor blade angles), at. nearly equal rotor speeds; and (3) mismatching the forward and aft rotor rotational speeds, by varying the aft rotor rotational speed, at both unequal and nearly equal power on the rotors.

\section{Overall Propeller Performance}

In table IV, the take-off target operating points, or the desired propeller operating conditions, for each propeller configuration tested are listed. As can be seen in the table, each propeller configuration had more than one set of take-off operating point blade angles (except the F11/A11 11/9 configuration). For the F7/A7 $8 / 8$ configuration, the blade angles produced the same desired take-off operating point power at different propeller tip speeds. For the remaining propeller configurations, the higher blade angle settings produced more power (a higher power loading parameter) while at the operating point.

The overall propeller performance results are presented in terms of the propeller net efficlency ( $n_{n e t}$ ) and advance ratio ( $J$ ) as a function of the propeller power loading parameter $\left(P Q A / J^{3}\right)$. The power loading parameter is a dimensionless measure of the power absorbed by the propeller at a constant flight velocity. In this way, the performance of several propeller configurations at different blade angles, but having the same target operating point power loading, can be more easily compared to each other and to desired target operating conditions from table IV.

Propeller net efficiency is defined as,

$$
n_{\text {net }}=T_{n e t}\left(\frac{V_{0}}{P}\right)
$$


or, in dimensionless form,

$$
\eta_{\text {net }}=\operatorname{TQA}\left(\frac{\mathrm{J}}{\mathrm{PQA}}\right)
$$

In the dimensionless form, the propeller. performance parameters are referenced to the propeller forward rotor.

The performance for several propeller configurations at different take-off target operating point power loadings is shown in figures 7 to 9 . In figure 7 , the performance of the F7/A7 $8 / 8$ and $11 / 9$ and the F7/A3 11/9 propeller configurations is shown. The blade angle settings shown represent a take-off target operating point power loading parameter of 3.83 for each configuration. In the F7/A7 8/8 configuration, two sets of blade angles were tested; at the same target operating point power loading parameter, one set of blade angles had a higher propeller tip speed than the other set (table IV). As can be seen in figure $7(a)$, the spread in propeller net efficiency was approximately 2.4 percent at the target operating point power loading parameter of 3.83 . The FT/A7 $11 / 9$ configuration demonstrated the best performance, with a net efficiency of approximately 52.4 percent. The difference in net efficiency between the F7/A7 $8 / 8$ low-tip-speed and high-tip-speed blade angle settings is about 2.0 percent, with the lower tip speed blade angles having a higher net efficiency of about 52.0 percent. The net efficiency difference between the F7/A7 11/9 and $8 / 8$ configurations is very small, about 0.4 percent. The F7/A3 11/9 configuration, with a net efficiency of about 50.7 percent, did not perform quite as well as the $F 7 / A 711 / 9$ configuration (net efficiency 52.0 percent). In figure $7(b)$, the advance ratio as a function of the power loading parameter is shown for the propeller configurations. The advance ratios for all the configurations were only slightly off from the target operating point advance ratios at the takeoff target operating point power loading parameter of 3.83 (table IV).

In figure 8, the propeller performance of the F7/A7 and F7/A3 11/9 configurations are shown. The blade angle settings shown represent a take-off target operating point power loading parameter of 4.36 . In figure $8(a)$, the difference in propeller net efficiency between the two configurations is approximately 2.3 percent, with the F7/A7 performance being slightly better at approximately 49.6 percent. The performance of both propeller configurations in figure $8(a)$ is slightly lower at the target operating point power loading parameter of 4.36 than the performance of the same configurations in figure $7(a)$ at the target operating point power loading parameter of 3.83 (due to the approximately 13.8 percent increase in the target operating point power loading). The propeller blade tip speed, however, is about 6.7 percent lower for the blade angle settings in figure $8(a)$ than the blade angle settings in figure $7(a)$ at the target operating points (table IV). In figure $8(b)$, the advance ratio results as a function of the power loading parameter are shown for the F7/A7 and F7/A3 $11 / 9$ configurations. The advance ratio for both propeller configurations are close to the target operating point advance ratio (table IV) at the target operating point power loading parameter of 4.36 .

The performance of the Fll/All 11/9 propeller configuration is shown in figure 9. The take-off target operating point power loading parameter is very high at 5.22, but the propeller tip speed is nearly the same as the tip speed for the F7/A7 and F7/A3 configurations at the target operating point power 
loading parameter of 4.36 (table IV). The propeller net efficiency at the target operating point power loading parameter is approximately 46.3 percent. The performance of this configuration is lower than the performance of the previous propeller configurations (figs. $7(a)$ and $(b)$ ) since the target operating point power loading is higher. The advance ratio results are shown in figure $9(b)$. The propelier configuration advance ratio at the target operating point power loading parameter of 5.22 is shown to be slightly below the target operating point advance ratio (table IV).

\section{Rotor Spacing Effects}

The axial spacing between the propeller rotors is defined as the distance between the propeller blade pitch change axes on the forward and aft propeller rotors. Three axial rotor spacings were investigated - minimum, nominal and maximum. The nominal rotor. spacing refers to the spacing on the $F 7 / A 78 / 8$ configuration. The propeller rotors are separated $3.34 \mathrm{in}$. at minimum rotor spacing, 4.16 in. at nominal rotor spacing, and 5.90 in. at maximum rotor spacing.

The effect of varying the axial spacing between the propeller rotors on the performance of the F7/A7 $8 / 8$ and the F7/A3 11/9 propeller configurations is shown in figures 10 and 11 . The propeller performance is presented in terms of the propeller net efficlency and the aft-to-forward rotor torque ratio as a function of the propeller power loading parameter. The torque ratio results are shown to demonstrate the effect changing the axial rotor spacing has on the division of power between the propeller rotors. During this part of the investigation, the propeller rotors were run at nearly matched rotational speeds and the blade angle settings on the rotors were left unchanged when the rotor spacing was changed.

In figure 10 , the effect of rotor spacing on the $F 7 / A 78 / 8$ propeller configuration performance is shown. For this configuration, the axial rotor spacing was varied from maximum to nominal. As can be seen in figure $10(a)$, the propeller performance changed slightly with a change in the axial rotor spacing at a take-off target operating point power loading parameter of 3.83 . The difference in propeller net efficiency is approximately 0.4 percent, with the propeller performance better at the larger rotor spacing. The propeller net efficiency was 51.9 percent at maximum rotor spacing and 51.5 percent at nominal rotor spacing. In figure $10(b)$, the aft-to-forward torque ratio (which is a measure of the division in power between the rotors) increased approximately 6.2 percent with the change in rotor spacing, from a torque ratio of 1.038 at maximum rotor spacing to 1.100 at nominal rotor spacing. The results show the propeller performance was slightly better at more nearly matched torque on the rotors.

The effect of varying the axial rotor spacing on F7/A3 11/9 propeller performance is shown in figure 11. The axial rotor spacing was varied from maximum to minimum for this configuration. In figure $11(a)$, the total change in propeller performance with the change in axial rotor spacing is small at a target operating point power loading parameter of 3.83 . From maximum to nominal rotor spacing, the propeller net efficiency decreased approximately 0.5 percent (from 50.5 to 50.0 percent). From nominal to minimum rotor spacing, the decrease in net efficiency was almost negligible, about 0.2 percent (from 
50.0 to 49.8 percent). As seen previously in figure $10(a)$, the propeller performance is slightly higher at larger axial rotor spacing. The effect of varying the rotor spacing on the propeller aft-to-forward torque ratio is shown in figure $11(b)$. The torque ratio increased 4.5 percent from maximum to nominal rotor spacing (from 1.056 to 1.101 ) and 1.6 percent from nominal to minimum rotor spacing (from 1.101 to 1.117 ). The results from figures 10 and 11 indicate the propeller performance to be fairly insensitive to variations in the axial spacing between the propeller rotors.

\section{Aft Rotor Power Effects}

The effect of varying the aft propeller rotor power on the propeller performance was determined at matched rotor rotational speeds by changing the aft rotor blade angle settings. The forward rotor blade angles were not changed during this part of the investigation. The results of varying the aft rotor power are shown in figures 12 and 13 for the F7/A7 8/8 and F7/A3 11/9 propeller configurations.

In figure 12, the effect of changing the aft propeller rotor power on the performance of the F7/A7 $8 / 8$ propeller configuration is shown. The aft rotor power was increased by increasing the aft propeller blade angles in $3^{\circ}$ increments from the initial aft blade angle setting of $35.4^{\circ}$, while the forward blade angle setting was held at $36.2^{\circ}$. For this configuration, the initial forward and aft rotor blade angle settings corresponded to the high-tip-speed blade angles from table IV, which produced nearly matched rotor rotational speed and rotor power at the target operating point power loading parameter of 3.83. Figure 12(a) presents the propeller net efficiency results, and figure $12(b)$ presents the aft-to-forward torque ratio results at different aft rotor power levels. At the target operating point power loading parameter of 3.83 , increasing the aft blade angles from $35.4^{\circ}$ to $38.4^{\circ}$ had a small effect on the propeller performance, decreasing the propeller net efficiency only about 0.4 percent (from 51.9 to 51.5 percent), but increasing the torque ratio about 36.7 percent (from 1.040 to 1.407 ). Increasing the aft blade angles another $3^{\circ}$, from $38.4^{\circ}$ to $41.4^{\circ}$, had a somewhat larger effect on the propeller performance, decreasing the net efficiency about 1.3 percent (from 51.5 to 50.2 percent), while increasing the torque ratio nearly the same amount, or 38.8 percent (from 1.407 to 1.795 ).

The effect of changing the aft propeller power on the performance of the F7/A3 11/9 propeller configuration is shown in figure 13. The aft rotor power was increased by increasing the aft rotor blade angle setting $3.2^{\circ}$, from $40.3^{\circ}$ to $43.5^{\circ}$, while the forward rotor blade angle setting was held at $36.4^{\circ}$. In this case, the final blade angle settings corresponded to the target operating point blade angle settings at a power loading parameter of 3.83 (table IV), producing matched rotor rotational speed and matched rotor power. From figure $13(a)$, the propeller net efficiency decreased about 0.8 percent (from 50.9 to 50.1 percent) at the target operating point power loading parameter of 3.83 when the aft blade angle settings were increased. In figure 13(b), the torque ratio at the same power loading point increased about 28.4 percent (from 0.820 to 1.104 ) with an increase in the aft blade angles. The results from figures 12 and 13 seem to indicate that the propeller performance is fairly insensitive to mismatched propeller rotor power. 
During most of the investigation, the forward and aft propeller rotors were tested at nearly the same, or matched, rotational speeds. The effect of unequal, or mismatched, propeller rotor rotational speeds on the propeller performance was also determined at matched and mismatched power on the rotors by varying the aft rotor rotational speed. In this case, matched power on the rotors occurred during the mismatched rotor rotational speed condition. The effect mismatching rotor rotational speeds on the propeller performance is shown in figures 14 and 15 for the F7/A7 $8 / 8$ and the F7/A3 11/9 propeller configurations.

Figure 14 shows the effects mismatching the propelier rotor rotational speeds on the performance of the F7/A7 $8 / 8$ propeller configuration. At the take-off target operating point power loading parameter of 3.83 , the rotor speeds were mismatched approximately 7.9 percent, corresponding to a reduction of about $600 \mathrm{rpm}$ in aft rotor rotational speed. In figure 14(a), the change in the propeller net efficiency between the matched and mismatched propeller rotor speed cases was negligible (less than 0.2 percent) at the target operating point power loading parameter of 3.83 . However, the resuits in figure 14(b) show a decrease in the aft-to-forward torque ratio of approximately 28.0 percent (from 1.406 to 1.126 ) at the same power loading parameter. The more nearly matched rotor torque results corresponded to the mismatched rotor speed condition.

The effect on the F7/A7 8/8 propeller configuration performance of mismatching the rotor rotational speeds approximately 14.8 percent at the target operating point power loading parameter of 3.83 is shown in figure 15 . The difference in rotor speeds corresponded to a reduction of approximately $1100 \mathrm{rpm}$ in the aft rotor rotational speed. The increase in the propeller net efficiency, shown in figure $15(\mathrm{a})$, is approximately 1.5 percent (from 50.0 to 51.5) at the target operating point power loading parameter of 3.83 . The higher net efficiency was produced at the mismatched rotor speed condition. In figure $15(b)$, the decrease in the torque ratio at the target operating point power loading parameter of 3.83 was approximately 56.8 percent (from 1.785 to 1.217). The mismatched rotor speed condition corresponded to the more matched rotor torque. The results from figures 14 and 15 indicate that the propeller performance is fairly insensitive to mismatched propeller rotor rotational speeds.

\section{Reverse Thrust Performance}

The reverse thrust characteristics of the F7/A7 $8 / 8$ propeller configuration were investigated at several flight Mach numbers and rotational speeds for two propeller blade angle settings. As mentioned earlier, during the reverse thrust investigation, several of the $F 7$ forward rotor propeller blades suffered structural damage as a result of high blade stresses while operating in this off-design regime. Since the Fl propeller blades were geometrically similar to the $F 7$ blades (table I), and the propeller net efficiency was not critical during reverse thrust operation, the reverse thrust investigation was concluded using the Fl propeller blades in the forward rotor. No distinction is made in the reverse thrust results, however, between the F1/A7 and the F7/A7 propeller configurations. Figures 16 and 17 show the reverse thrust performance of the 
F7/A7 8/8 configuration at the two blade angle settings - one a flat-pitch setting on both propeller rotors $(0.0 / 0.0)$ and the other negative blade angle settings on both rotors $(-21.8 /-21.8)$.

In figure 16, the dimensionless reverse thrust propeller characteristics are shown in terms of the thrust loading parameter (TQA/J2) as a function of the power loading parameter at Mach numbers $0.10,0.15$, and 0.20 . At flatpitch blade angle settings, the thrust loading parameter is almost constant with rotor speed and flight Mach number. At the negative blade angle settings, larger changes in the thrust loading parameter occur since much larger changes in the power loading parameter occur with rotor speed and Mach number. Interestingly, the results indicate a smooth trend with propeller flight speed and rotor rotational speed at both blade angle settings.

In figure 17 , a ratio of the net reverse thrust produced to the net forward thrust produced at the take-off target operating point power loading parameter of 3.83 (blade angle settings $36.2 / 35.4$ ) is shown as a function of Mach number for 70 and 95 percent of design rotational speed (100 percent design rotational speed for the $F 7 / A 7$ configuration is $8371 \mathrm{rpm}$ ). The number used for the net forward thrust produced at the take-off target point power loading parameter of 3.83 was $625 \mathrm{lb}$ of force, at a Mach number of 0.20 . For comparison with the negative blade angle performance, the performance results of the flat-pitch blade angles at 95 percent design speed at Mach number 0.15 and 0.20 were extrapolated from lower rotational speed results. As can be seen in the figure, the negative blade angle settings produced a larger amount of reverse thrust than the flat-pitch blade angles at all Mach numbers. At Mach number 0.20 and 95 percent design speed, the negative biade angles produced reverse thrust equal to about 60.4 percent of the take-off net thrust, compared with the extrapolated result of 38.2 percent for the flat-pitch blade angles. At 70 percent design speed, the negative blade angles produced 44.2 percent of the take-off net thrust compared with 36.0 percent for the flat-pitch blade angles. Interestingly, at static fight conditions (Mach number 0.0 ) and 95 percent design speed, the negative blade angles produced reverse thrust equal to 43.5 percent of the take-off net thrust, while the flat-pitch blade angles produced 10.4 percent of the take-off net thrust.

The amount of reverse thrust produced by the F7/A7 8/8 propeller configuration at both blade angle settings exceeds the amount of reverse thrust produced by a typical high-bypass turbofan at nearly all Mach numbers. The typical turbofan produces reverse thrust equal to about 21 percent of the take-off net thrust at Mach number 0.20 and about 2.5 percent of the take-off net thrust at Mach number 0.0 (ref. 6).

\section{SUMMARY OF RESULTS}

The low-speed aerodynamic performance characteristics of several advanced counterrotation pusher-propeller configurations, designed for cruise Mach numbers of 0.72 and 0.80 , were investigated in the NASA Lewis 9- by 15-Foot Low Speed Wind Tunnel in support of the Advanced Turboprop Project. The investigation was conducted at Mach numbers representative of the take-off/landing flight regime. The investigation included: (1) the propeller performance characteristics over a range of blade angle settings and rotational speeds at a Mach number of 0.20 ; (2) the effect on the propeller performance of varying 
the axial rotor spacing and mismatching the propeller rotor power and propeller rotor rotational speeds; and (3) determining the reverse thrust performance characteristics at Mach numbers of $0.0,0.10,0.15$, and 0.20 . The results obtained from the investigation indicate the following:

1. The high-speed counterrotation propellers have reasonable propeller net efficiency at low-speed flight conditions. The F7/A7 11/9 propeller configuration had the highest propeller net efficlency at the take-off target operating points (table IV). At a take-off target operating point power loading parameter of 3.83, the F7/A7 $11 / 9$ propeller net efficiency was about 52.4 percent, while the F7/A7 $8 / 8$ configuration performance was slightly lower with a propeller net efficiency of about 52.0 percent at the high-tip-speed blade angles and 50.0 percent at the low-tip-speed blade angles (table IV). At the same target operating point, the propeller net efficiency of the F7/A3 11/9 configuration was about 50.7 percent. At a higher target operating point power loading parameter of 4.36 , the propeller net efficiency was about 49.6 percent for the F7/A7 11/9 configuration and about 47.3 percent for the $F 7 / A 311 / 9$ configuration. At the highest target operating point power loading parameter of 5.22 , the $F 11 / A 1111 / 9$ configuration (which was the only configuration tested at this target operating point) had a propeller net efficiency of about 46.4 percent.

2. The performance of the counterrotation propellers is fairly insensitive to changes in axial rotor spacing. By increasing the axial spacing from maximum to nominal on the $F 7 / A 78 / 8$ configuration, the propeller net efficiency decreased about 0.4 percent (from 51.9 to 51.5 percent), and the aft-to-forward torque ratio increased about 6.2 percent (from 1.038 to 1.100 ), at a target operating point power loading parameter of 3.83. The F7/A3.11/9 configuration showed similar performance results for variations in axial rotor spacing from maximum to minimum at the same target operating point power loading parameter of 3.83. From maximum to nominal rotor spacing, the propeller net efficiency decreased about 0.5 percent (from 50.5 to 50.0 percent) with an increase in the torque ratio of 4.5 percent (from 1.056 to 1.101). From nominal to minimum, the change in propeller net efficiency was almost negligible, only about 0.2 percent, and an increase in torque ratio of 1.6 percent (from 1.101 to 1.117). For both propeller configurations, the performance was better at the larger axial rotor spacings and more nearly matched rotor torque (more matched rotor power).

3. The performance of the counterrotation propellers is fairly insensitive to mismatches in rotor power. The aft propeller rotor power was varied on the F7/A7 $8 / 8$ configuration by increasing the aft rotor blade angle setting. With a $3^{\circ}$ increase in the aft rotor blade angle setting (from 35.4 to 38.4 ), the propeller net efficiency decreased 0.4 percent (from 51.9 to 51.5 percent) with a 36.7 percent increase in the torque ratio (from 1.040 to 1.407 ) at the target operating point power loading parameter of 3.83. Increasing the aft blade angles another $3^{\circ}$ (from $38.4^{\circ}$ to $41.4^{\circ}$ ), the propeller net efficiency decreased another 1.3 percent (from 51.5 to 50.2 percent) with an additional 38.8 percent increase in the torque ratio (from 1.407 to 1.795). At the same target operating point power loading parameter, the F7/A3 11/9 configuration performance showed a similar insensitivity to changes in the aft power. Increasing the aft rotor blade angles setting $3.2^{\circ}$ (from 40.3 to 43.5 ), the propeller net efficiency decreased 0.8 percent (from 50.9 to 50.1 ) with a 28.4 percent increase in the torque ratio (from 0.820 to 1.104 ). The best performance for both 
propeller configurations occurred at the more nearly matched rotor torque conditions.

4. The performance of the counterrotation propellers is fairiy insensitive to $\mathrm{mismatched}$ propeller rotor rotational speeds. The rotational speeds were mismatched on the F7/A7 $8 / 8$ configuration by reducing the aft rotor rotational speed. With a 7.9 percent difference in the rotor speeds (a reduction of $600 \mathrm{rpm}$ in the aft rotor rotational speed), the change in the propeller net efficiency was negligible (less than 0.2 percent), with a decrease in the torque ratio of 28.0 percent (from 1.406 to 1.126 ), at the target operating point power loading parameter of 3.83. With a 14.8 percent difference in rotor speeds (a reduction of $1100 \mathrm{rpm}$ in the aft rotor rotational speed), the propeller net efficiency increased 1.5 percent (from 50.0 to 51.5 ) with a 56.8 percent decrease in the torque ratio (from 1.785 to 1.217). The best propeller performance was at the more nearly matched rotor torque.

5. The F7/A7 8/8 counterrotation propeller configuration produced a reasonable amount of reverse thrust at flight Mach numbers from 0.0 to 0.20 . The largest amount of reverse thrust was produced at 95 percent of design speed (100 percent design speed equals $8371 \mathrm{rpm}$ ) at Mach number 0.20 . The negative propeller blade angle settings produced more reverse thrust than the flat-pitch blade angle settings at all propeller speeds and Mach numbers. The negative blade angle settings produced reverse thrust equal to about 60.4 percent of the take-off point net thrust $(625 \mathrm{lb}$ of force at a take-off target operating point power loading parameter of 3.83) at Mach number 0.20 and 95 percent of design speed. In comparison, the extrapolated results at the flat-pitch blade angle settings indicated reverse thrust equal to about 38.2 percent of the take-off net thrust at the same speed could be produced. At static flight conditions (Mach number 0.0 ) and 95 percent design speed, the reverse thrust produced at negative blade angles was equal to about 43.5 percent of the take-off net thrust, while 10.4 percent was produced by the flat-pitch blade angles at the same conditions.

\section{REFERENCES}

1. Stefko, G.L., Rose, G.E., and Podboy, G.G., "Wind Tunne] Performance Results of an Aeroelastically Scaled $2 / 9$ Model of the PTA Flight Test Prop/Fan," AIAA Paper 87-1893, June 1987. (NASA TM-89917.)

2. Whitlow, J.B., Jr., and Sievers, G.K., "Fuel Savings Potential of the NASA Advanced Turboprop Program," NASA TM-83736, 1984.

3. Hughes, C.E., "Flowfield Measurements in the NASA Lewis Research Center 9- by 15-Foot Low Speed Wind Tunne1," NASA TM-100883, 1988.

4. Delaney, B.R., Balan, C., West, H., Humenik, F.M., and Craig, G., "A Model Propulsion Simulator for Evaluating Counter Rotating Blade Characteristics," SAE Paper 861715, Oct. 1986.

5. Smith, L.H., Jr., "Unducted Fan Aerodynamic Design," Journal of Turbomachinery, Vol. 109, No. 3, July 1987, pp. 313-324. 
6. Stefko, G.L., and Jeracki, R.J., "Wind-Tunnel Results of Advanced High-Speed Propeliers at Takeoff, Climb, and Landing Mach Numbers," NASA TM-87030, 1985.

TABLE I. COUNTERROTATION PROPELLER MODEL BLADE DESIGN CHARACTERISTICS

[ Value in Parenthesis Indicates A3 Activity Factor Based on the A7 Propeller Blade Diameter ]

\begin{tabular}{|l|c|c|c|c|c|c|}
\hline & F1 & F7 & F11 & A3 & A7 & A11 \\
\hline Design Mach Number & 0.72 & 0.72 & 0.80 & 0.72 & 0.72 & 0.80 \\
$\begin{array}{l}\text { Activity Factor } \\
\text { per Blade }\end{array}$ & 150 & 150 & 180 & $240(125)$ & 150 & 200 \\
$\begin{array}{l}\text { Tip Sweep Angle, deg } \\
\begin{array}{l}\text { Reference Diameter, in } \\
\text { Ratio of Hub Diameter } \\
\text { to Propeller Diameter }\end{array}\end{array}$ & 33 & 34 & 37 & 24 & 31 & 34 \\
\hline
\end{tabular}

TABLE II. COUNTERROTATION PROPELLER DESIGN CHARACTERISTICS

[ Value in Parenthesis Indicates F7/A3 Configuration Total Activity Factor Based On Determination of A3 Activity Factor Using A7 Propeller Diameter ]

\begin{tabular}{|l|c|c|c|c|c|}
\hline & $\begin{array}{c}\text { Design Mach } \\
\text { Number/Altitude }\end{array}$ & $\begin{array}{c}\text { Power Loading, } \\
\text { SHP/D }\end{array}$ & $\begin{array}{c}\text { Number of Blades } \\
\text { (Forward/Aft) }\end{array}$ & $\begin{array}{c}\text { Total Activity } \\
\text { Factor }\end{array}$ & Tip Speed, fps \\
\hline F7/A7 & $0.72 / 35000 \mathrm{ft}$ & 55 & $8 / 8$ & 2400 & 780 \\
\hline F7/A3 & $0.72 / 35000 \mathrm{ft}$ & 69 & $11 / 9$ & 3000 & 780 \\
\hline F11/A11 & $0.80 / 35000 \mathrm{ft}$ & 77 & $11 / 9$ & $3810(2775)$ & 780 \\
\hline
\end{tabular}


TABLE III. COUNTERROTATION PROPELLER GEOMETRY SUMMARY

[ Test Matrix Conducted at Mach Number 0.20; Reverse Thrust Conducted at Mach Numbers From 0.0 to 0.20 ; Negative Blade Angles Indicate Reverse Thrust Settings ]

\begin{tabular}{|c|c|c|c|}
\hline $\begin{array}{c}\text { Propeller } \\
\text { Configuration }\end{array}$ & $\begin{array}{l}\text { Blade Number } \\
\text { (Forward/Aft) }\end{array}$ & $\begin{array}{l}\text { Blade Angles } \\
\text { (Forward/Aft) }\end{array}$ & $\begin{array}{c}\text { Rotor } \\
\text { Spacing }\end{array}$ \\
\hline \multirow{5}{*}{ F7/A7 } & \multirow{3}{*}{$8 / 8$} & $36.2 / 35.4$ & \multirow{3}{*}{$\begin{array}{l}\text { Nominal } \\
\text { Maximum }\end{array}$} \\
\hline & & $41.8 / 38.4$ & \\
\hline & & $-21.8 /-21.8$ & \\
\hline & \multirow{2}{*}{$11 / 9$} & $36.4 / 36.5$ & \multirow{2}{*}{ Maximum } \\
\hline & & $41.1 / 39.4$ & \\
\hline \multirow{4}{*}{ F7/A3 } & \multirow{4}{*}{$11 / 9$} & $36.4 / 40.3$ & \multirow{2}{*}{ Nominal } \\
\hline & & $36.4 / 41.7$ & \\
\hline & & $36.4 / 43.5$ & $\begin{array}{l}\text { Minimum } \\
\text { Nominal } \\
\text { Maximum }\end{array}$ \\
\hline & & $41.1 / 46.4$ & \multirow{2}{*}{ Maximum } \\
\hline F11/A11 & $11 / 9$ & $42.4 / 41.1$ & \\
\hline \multirow{2}{*}{ F1/A7 } & \multirow{2}{*}{$8 / 8$} & $-21.8 /-21.8$ & \multirow{2}{*}{ Nominal } \\
\hline & & $0.0 / 0.0$ & \\
\hline
\end{tabular}

TABLE IV. COUNTERROTATION PROPELLER TAKE-OFF TARGET OPERATING POINTS

\begin{tabular}{|c|c|c|c|c|c|c|}
\hline $\begin{array}{c}\text { Propeller } \\
\text { Configuration }\end{array}$ & $\begin{array}{l}\text { Numiner of Blades } \\
\text { (Forward/Aft) }\end{array}$ & $\begin{array}{l}\text { Blade Angles } \\
\text { (Forward/Aft) }\end{array}$ & Tip Speed, fps & $\begin{array}{c}\text { Advance Ratio, } \\
\mathcal{J}\end{array}$ & $\begin{array}{c}\text { Power coefficient, } \\
\text { PQA }\end{array}$ & $\begin{array}{c}\text { Power Loading } \\
\text { Parameter, } \\
\text { PQA } / J^{3}\end{array}$ \\
\hline \multirow{4}{*}{ F7/A7 } & \multirow{2}{*}{$8 / 8$} & $36.2 / 35.4$ & 850 & .825 & 2.150 & 3.83 \\
\hline & & $41.8 / 38.4$ & 760 & .923 & 3.010 & 3.83 \\
\hline & \multirow{2}{*}{$11 / 9$} & $36.4 / 36.5$ & 815 & .861 & 2.444 & 3.83 \\
\hline & & $41.1 / 39.4$ & 760 & .923 & 3.432 & 4.36 \\
\hline \multirow{2}{*}{ F7/A3 } & \multirow{2}{*}{$11 / 9$} & $36.4 / 43.5$ & 815 & .861 & 2.444 & 3.83 \\
\hline & & $41.1 / 46.4$ & 760 & .923 & 3.432 & 4.36 \\
\hline $\mathrm{F} 11 / \mathrm{A} 11$ & $11 / 9$ & $42.4 / 41.1$ & 770 & .911 & 3.944 & 5.22 \\
\hline
\end{tabular}




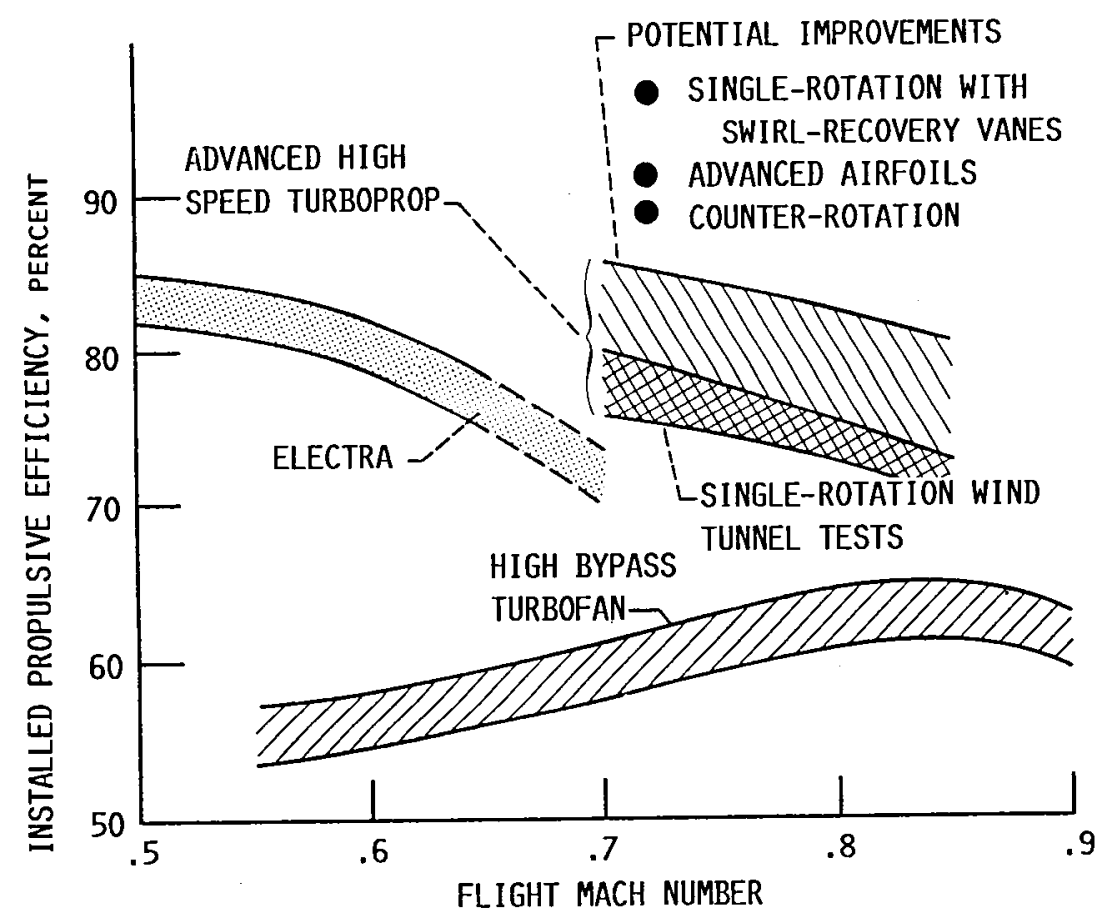

FIGURE 1. - INSTALLED PROPULSIVE EFFICIENCY TRENDS OF ADVANCED TURBOPROPS COMPARED WITH EQUIVALENT TECHNOLOGY TURBOFANS.

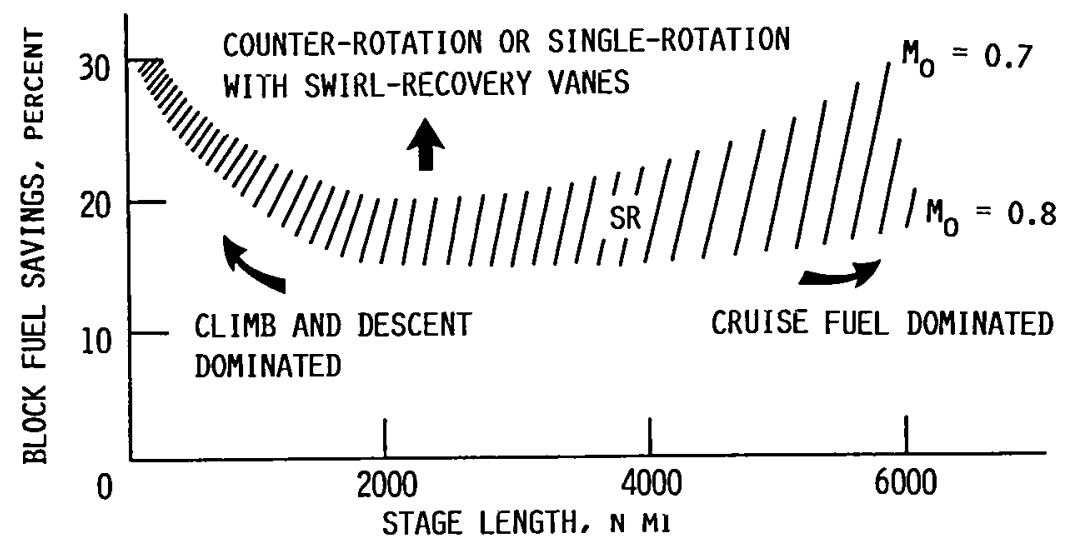

FIGURE 2. - FUEL SAVINGS TRENDS OF ADVANCED TURBOPROP AIRCRAFT OVER COMPARABLE TURBOFAN AIRCRAFT. 


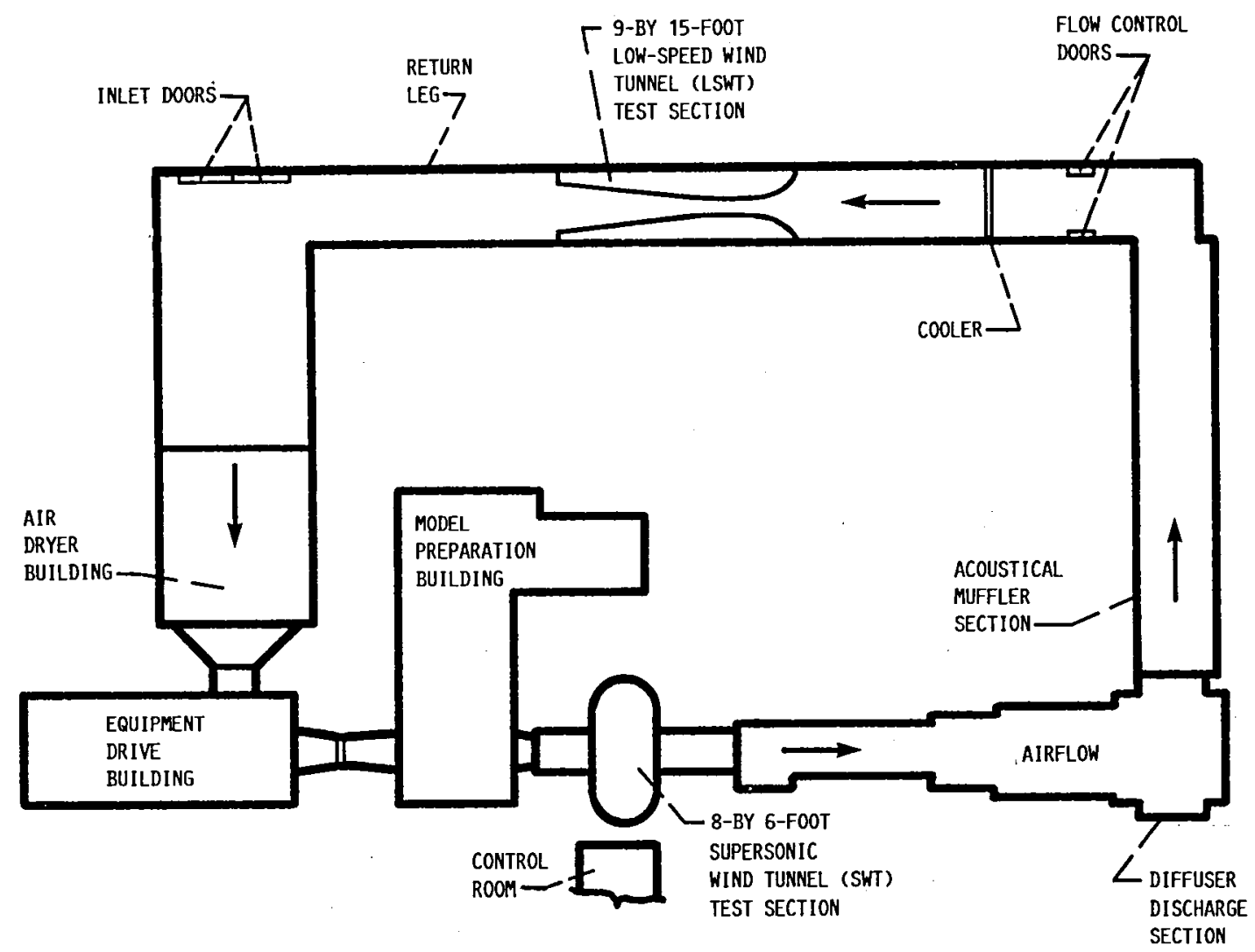

(a) OVERALL PLAN VIEW.

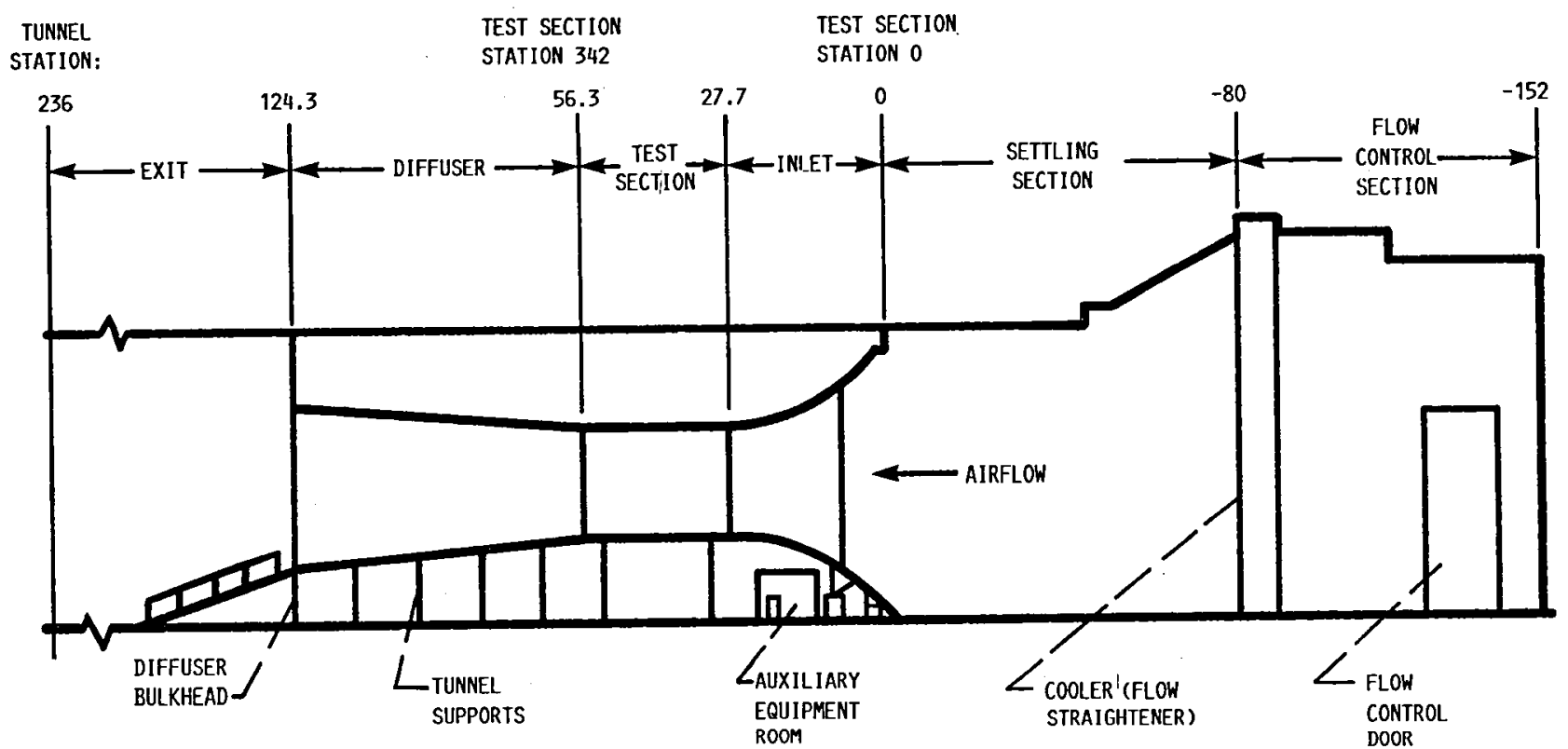

(b) SCHEMATIC ELEVATION VIEW OF 9-BY 15-FOOT TEST SECTION.

FIGURE 3. - GEOMETRY OF THE NASA LEWIS RESEARCH CENTER 9- BY 15 FOOT LOW SPEED WIND TUNNEL. 


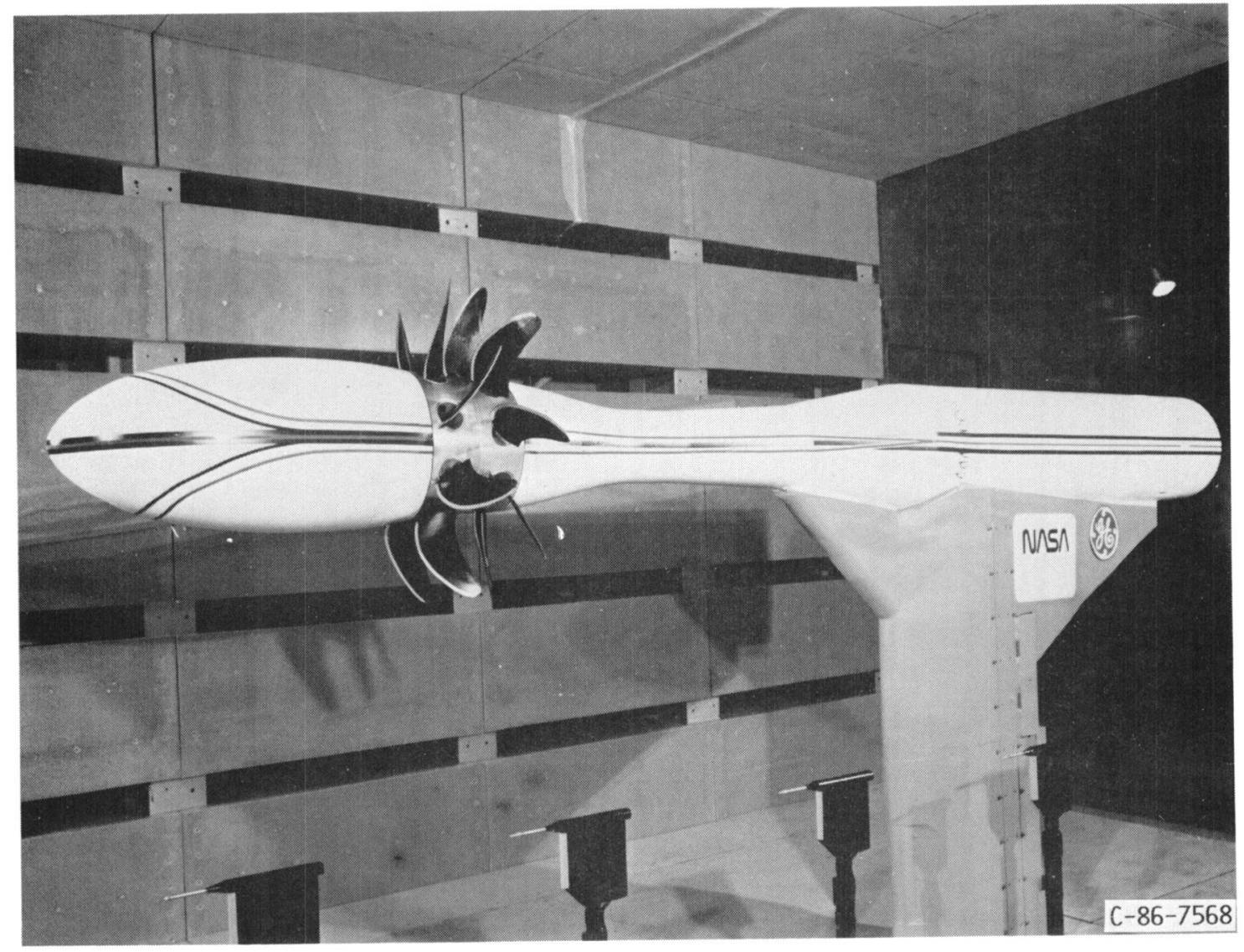

FIGURE 4. - MODEL COUNTERROTATION PROPELLER TEST RIG (CRP/PTR) WITH MODEL PROPELLER BLADES INSTALLED IN 9- BY 15-FOOT LOW-SPEED WIND TUNNEL TEST SECTION. 


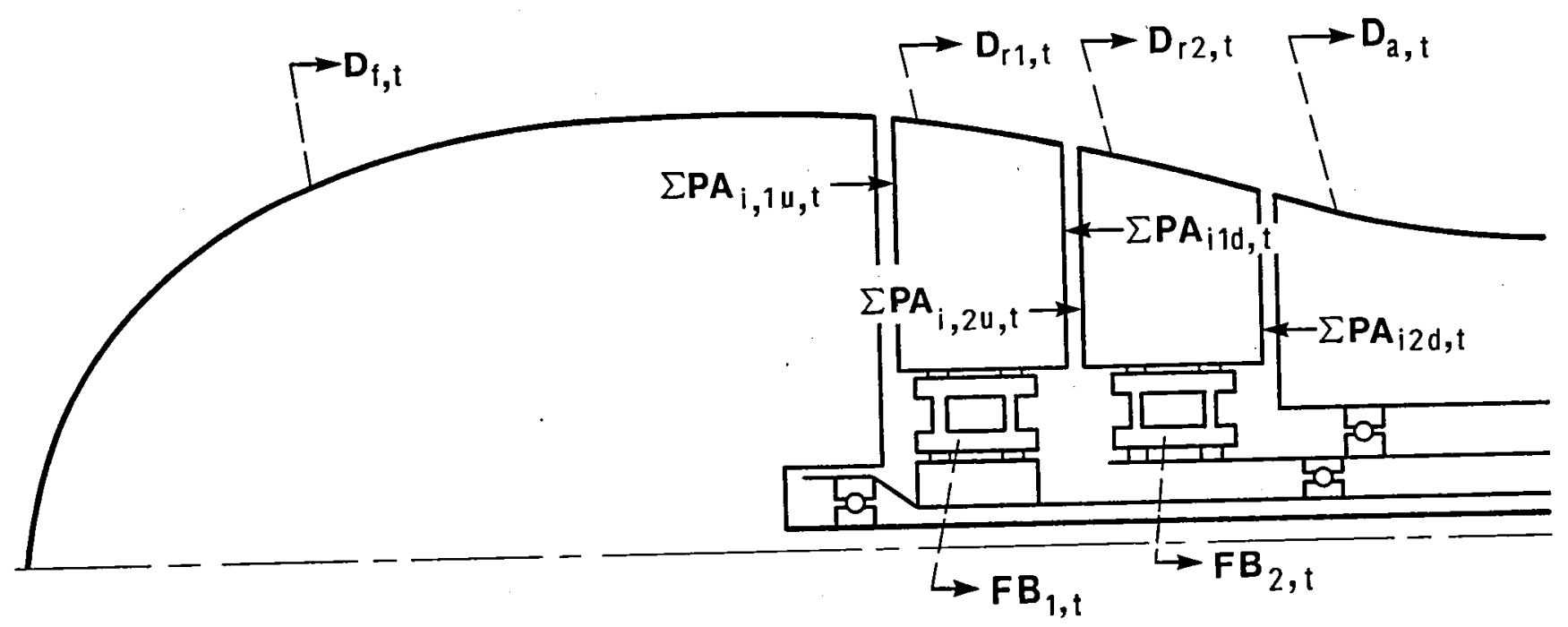

(a) TARE (PROPELLER BLADES OFF) FORCES.

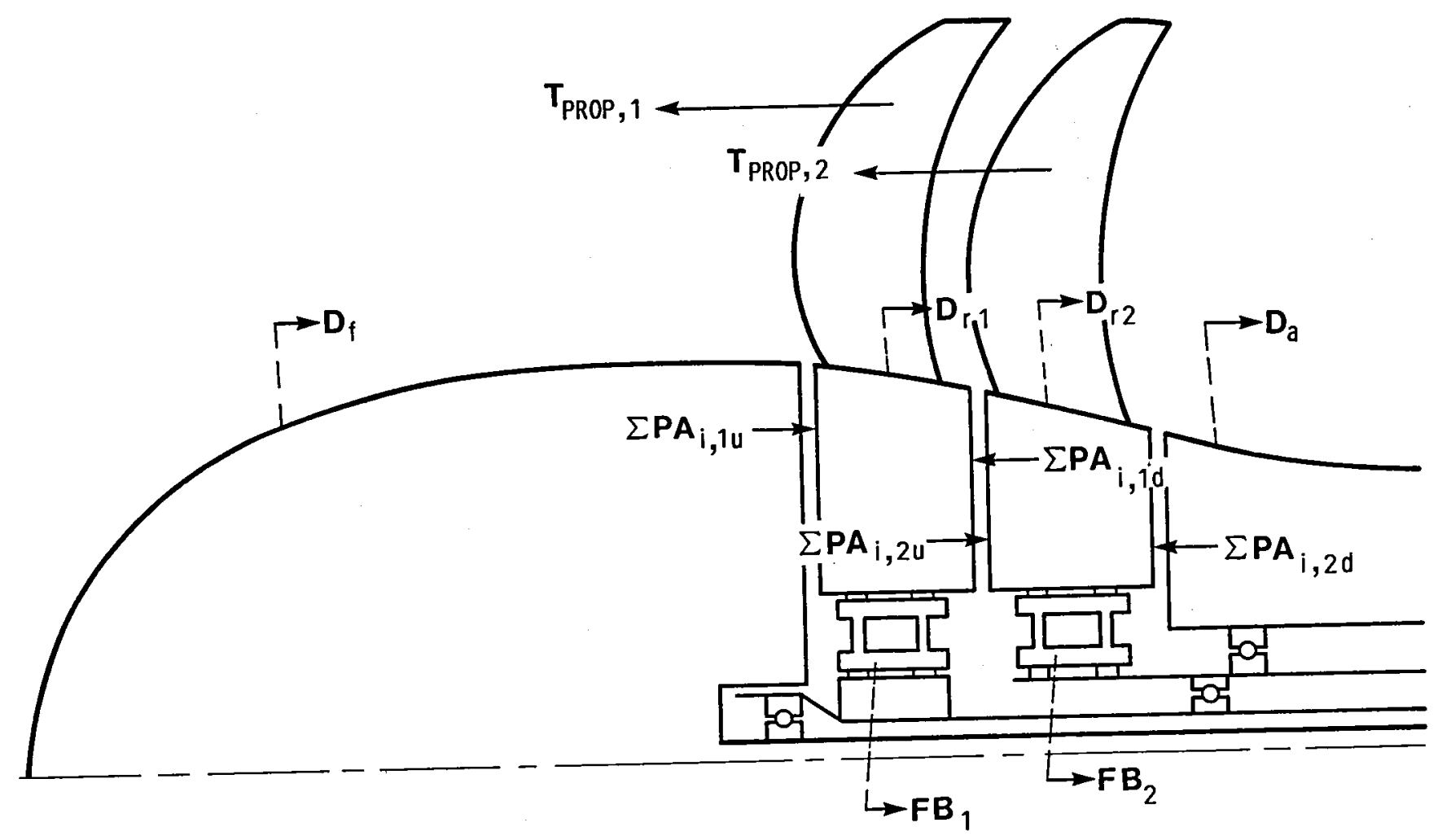

(b) POWERED (PROPELLER BLADES ON) FORCES.

FIGURE 5. - FORCES ON COUNTERROTATION PROPELLER TEST RIG. 

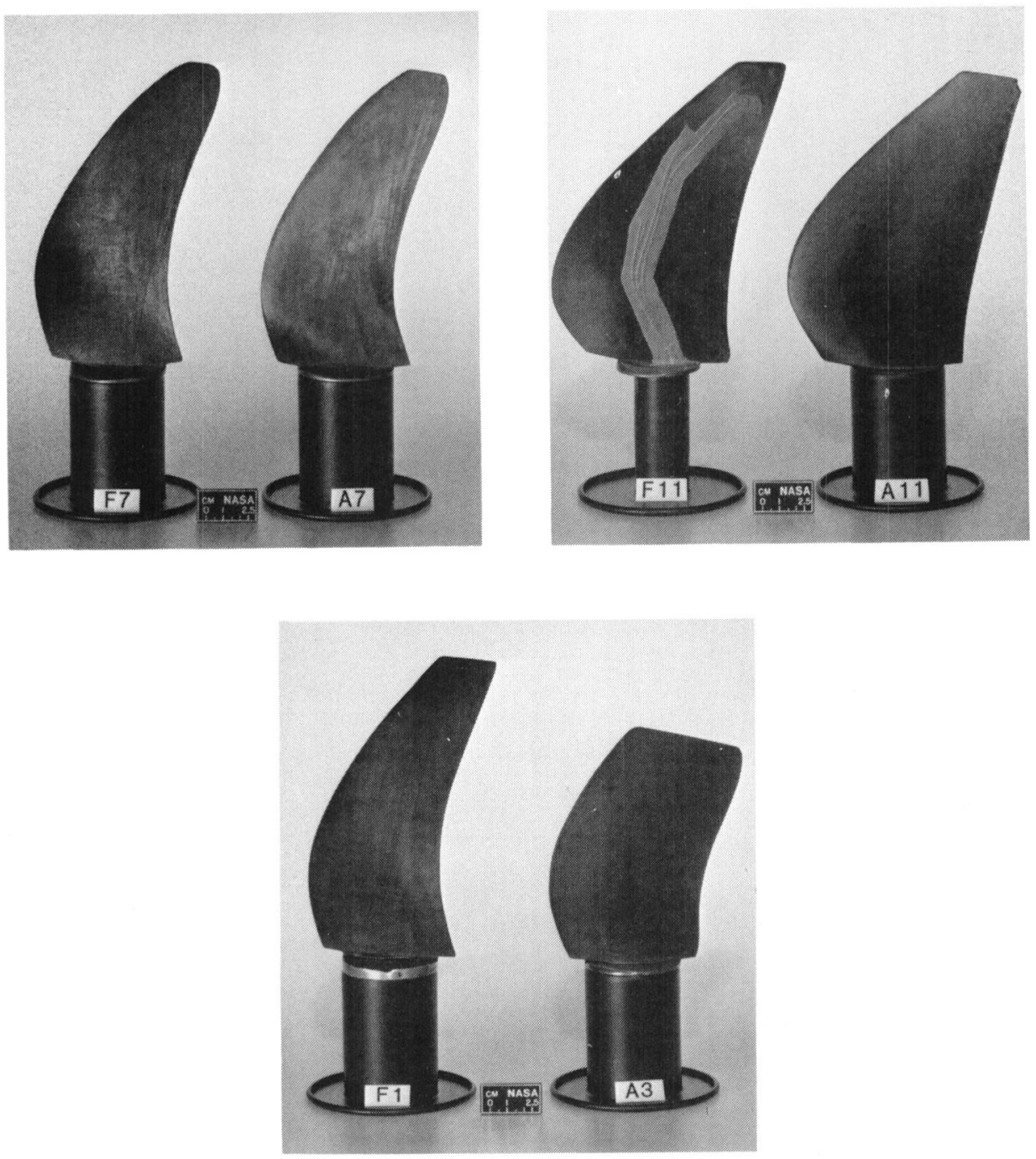

FIGURE 6. - MODEL COUNTERROTATION PROPELLER BLADES TESTED IN 9- BY 15-FO0T LOW-SPEED WIND TUNNEL. 


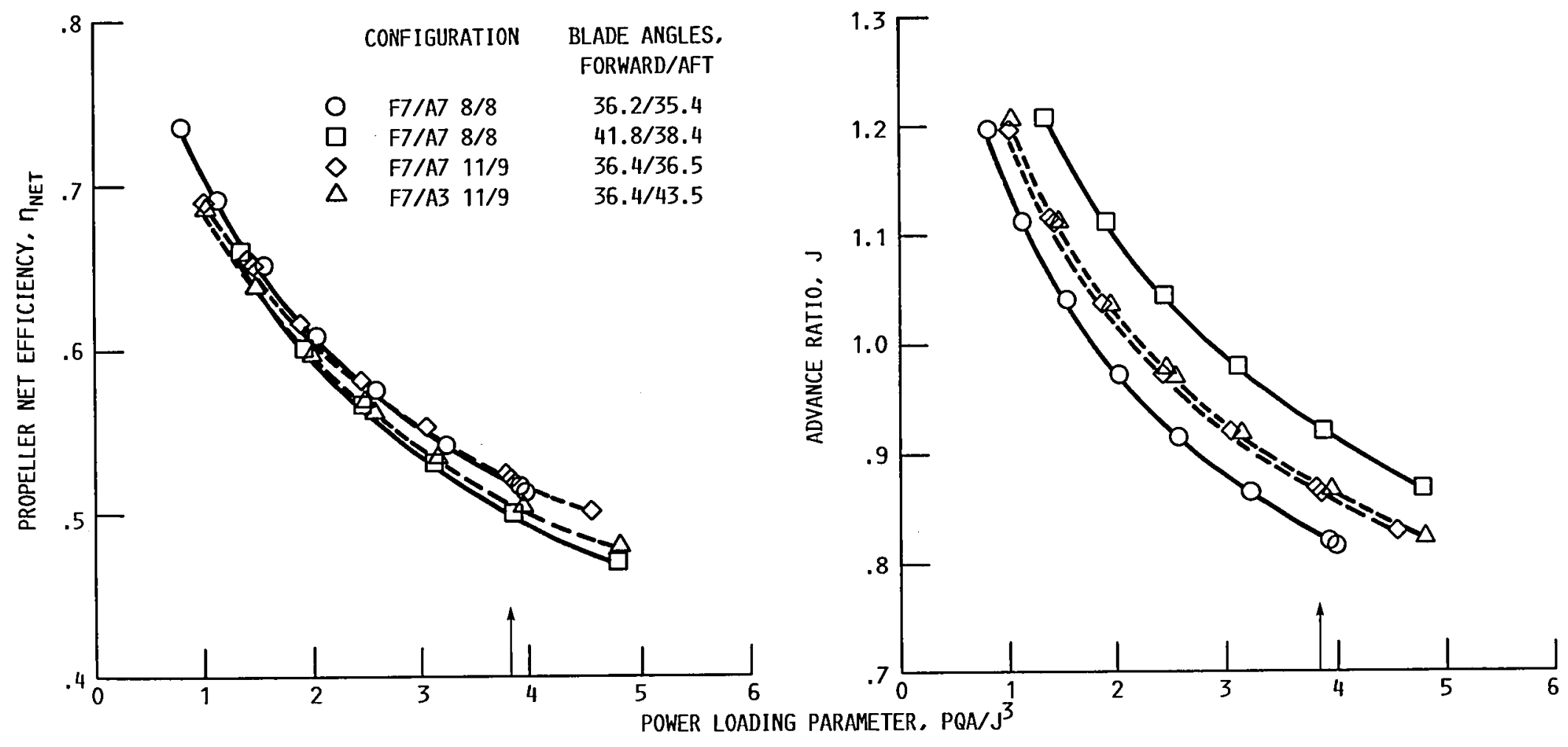

(a) PROPELLER NET EFFICIENCY.

(b) ADVANCE RATI0.

FIGURE 7. - COUNTERROTATION PROPELLER PERFORMANCE (TAKE-OFF TARGET OPERATING POINT POWER LOADING PARAMETER OF 3.83) AT MACH NUMBER 0.20 . 


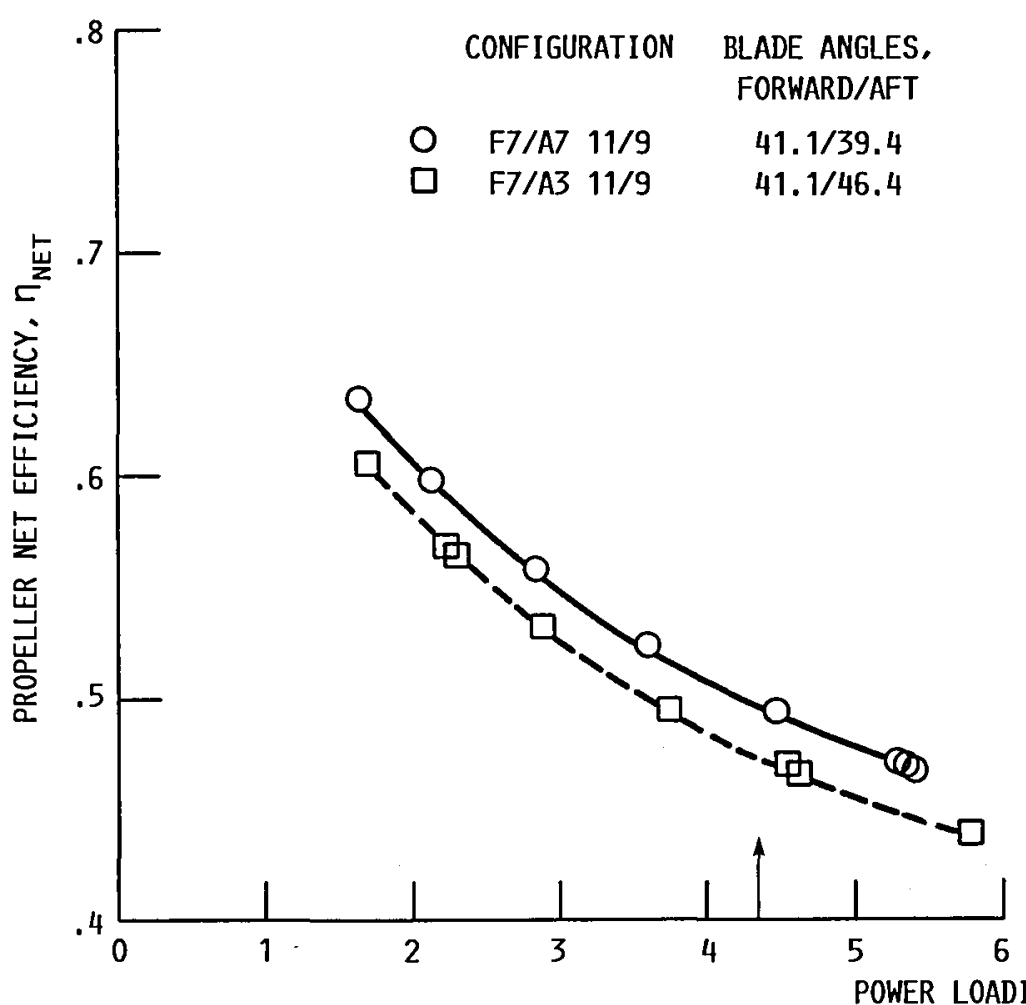

(a) PROPELLER NET EFFICIENCY.

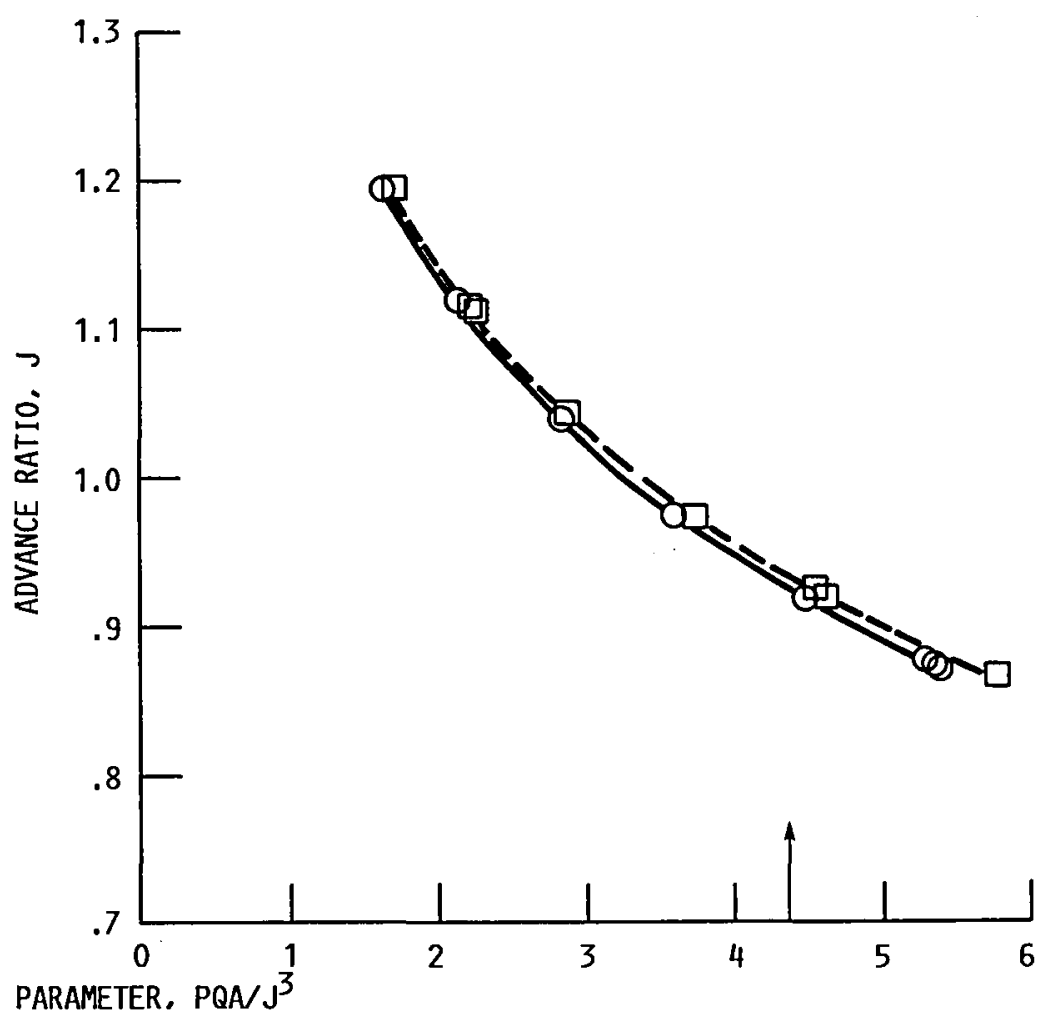

(b) ADVANCE RATIO.

FIGURE 8. - COUNTERROTATION PROPELLER PERFORMANCE (TAKE-OFF TARGET OPERATING POINT POWER LOADING PARAMETER OF 4.36) AT MACH NUMBER 0.20 . 


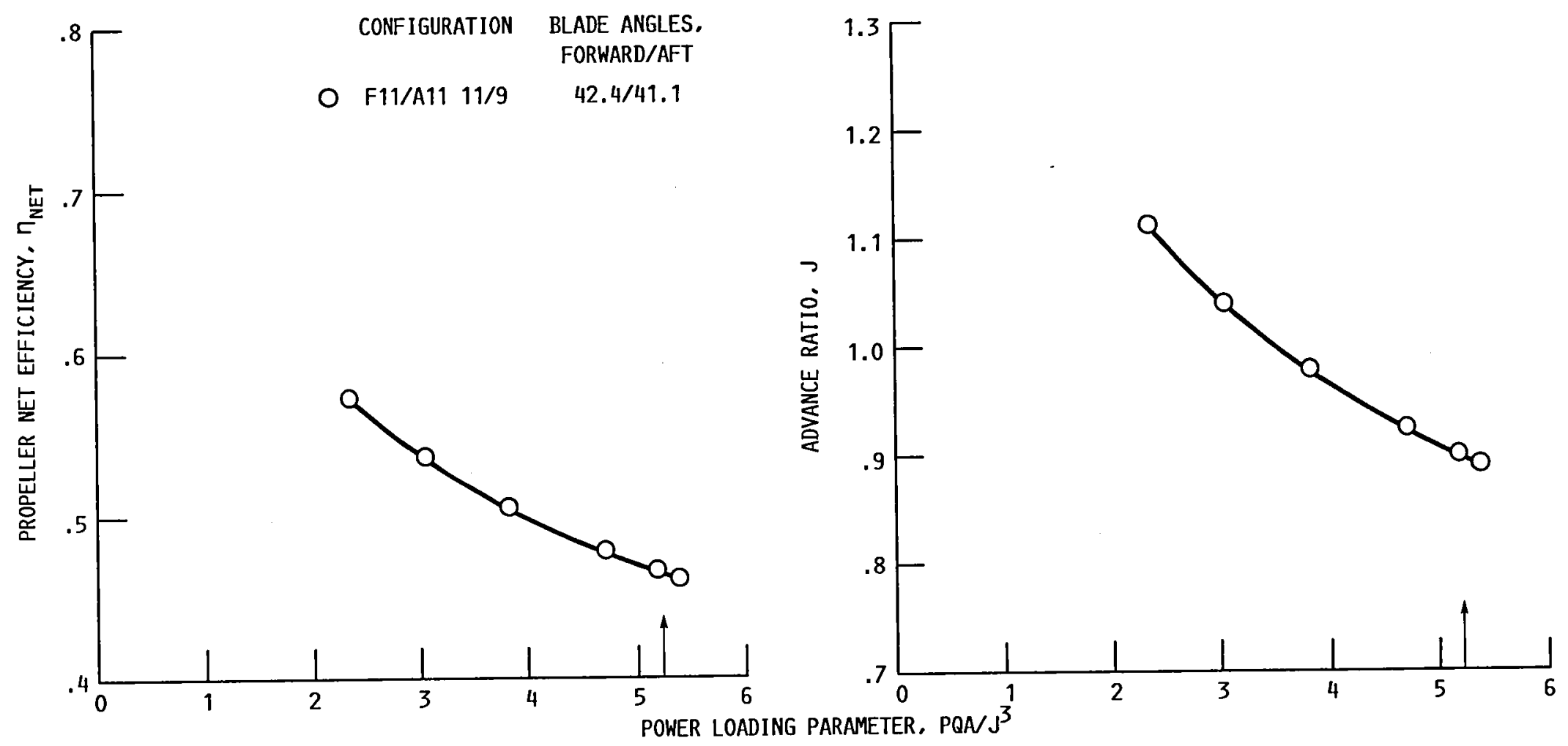

(a) PROPELLER NET EFFICIENCY.

(b) ADVANCE RATIO.

Figure 9. - COUNTERROTATION PROPELLER PERFORMANCE (TAKE-OFF TARGET OPERATING POINT POWER LOADING PARAMETER OF 5.22) AT MACH NUMBER 0.20 . 


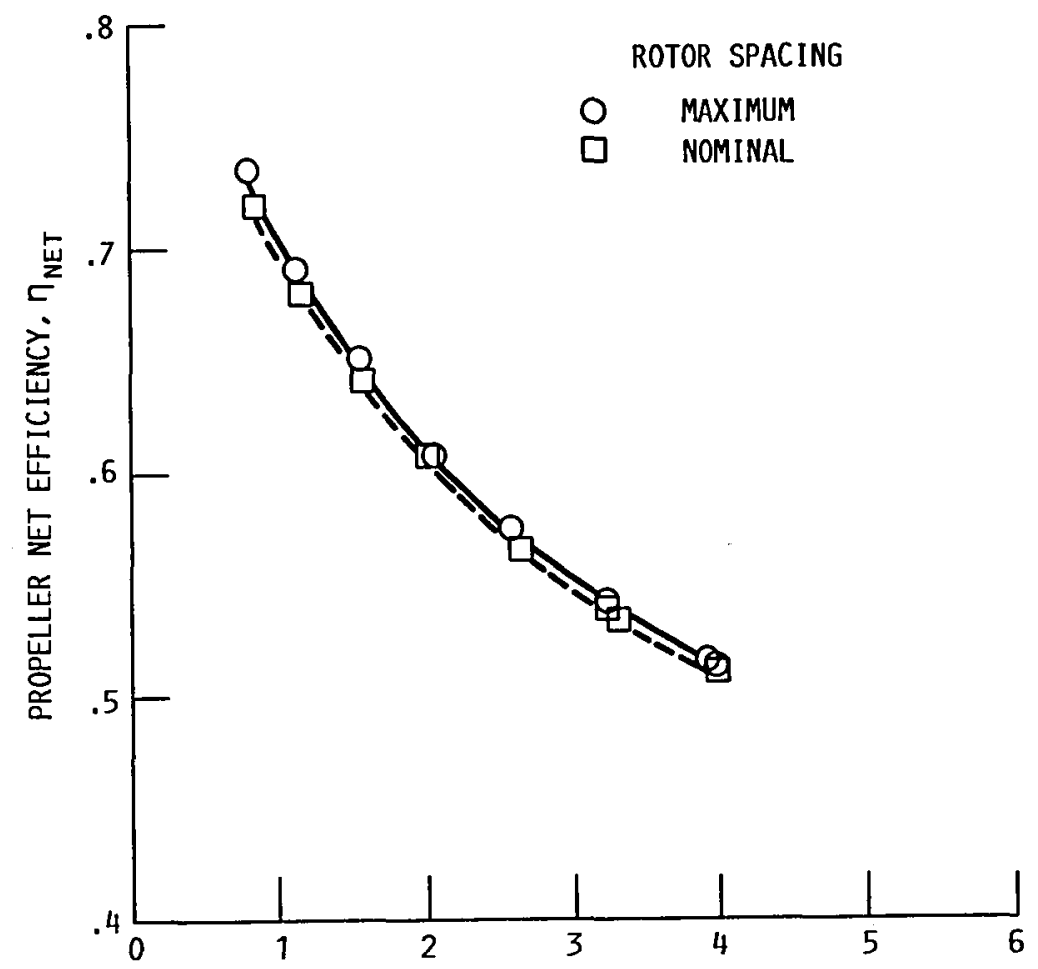

(a) PROPELLER NET EFFICIENCY.

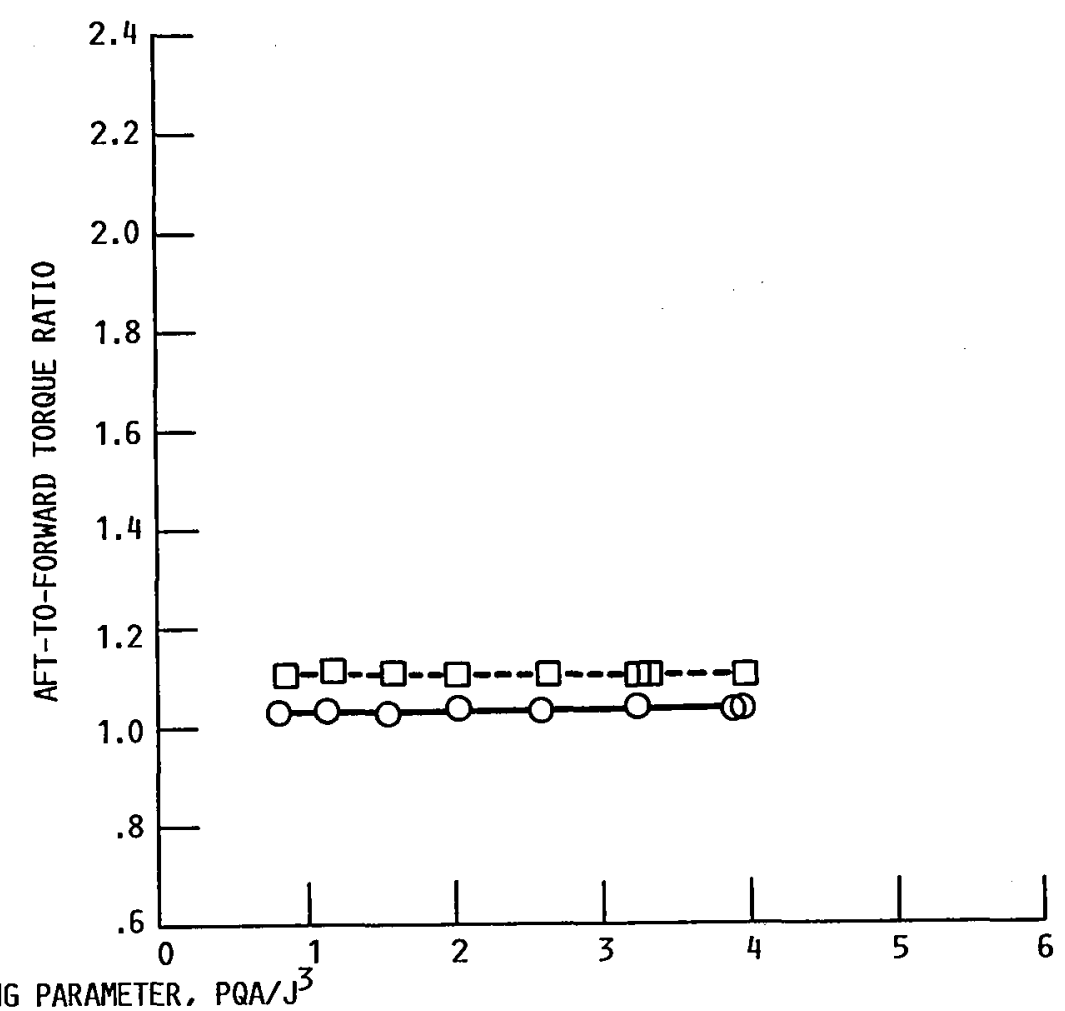

(b) AFT-TO-FORWARD TORQUE RATIO.

FIGURE 10. - EFFECT OF AXIAL ROTOR SPACING ON F7/A7 8/8 PROPELLER PERFORMANCE AT MACH NUMBR 0.20 AND BLADE ANGLES 36.2/35.4 (TAKE-OFF POINT POWER LOADING PARAMETER OF 3.83). 

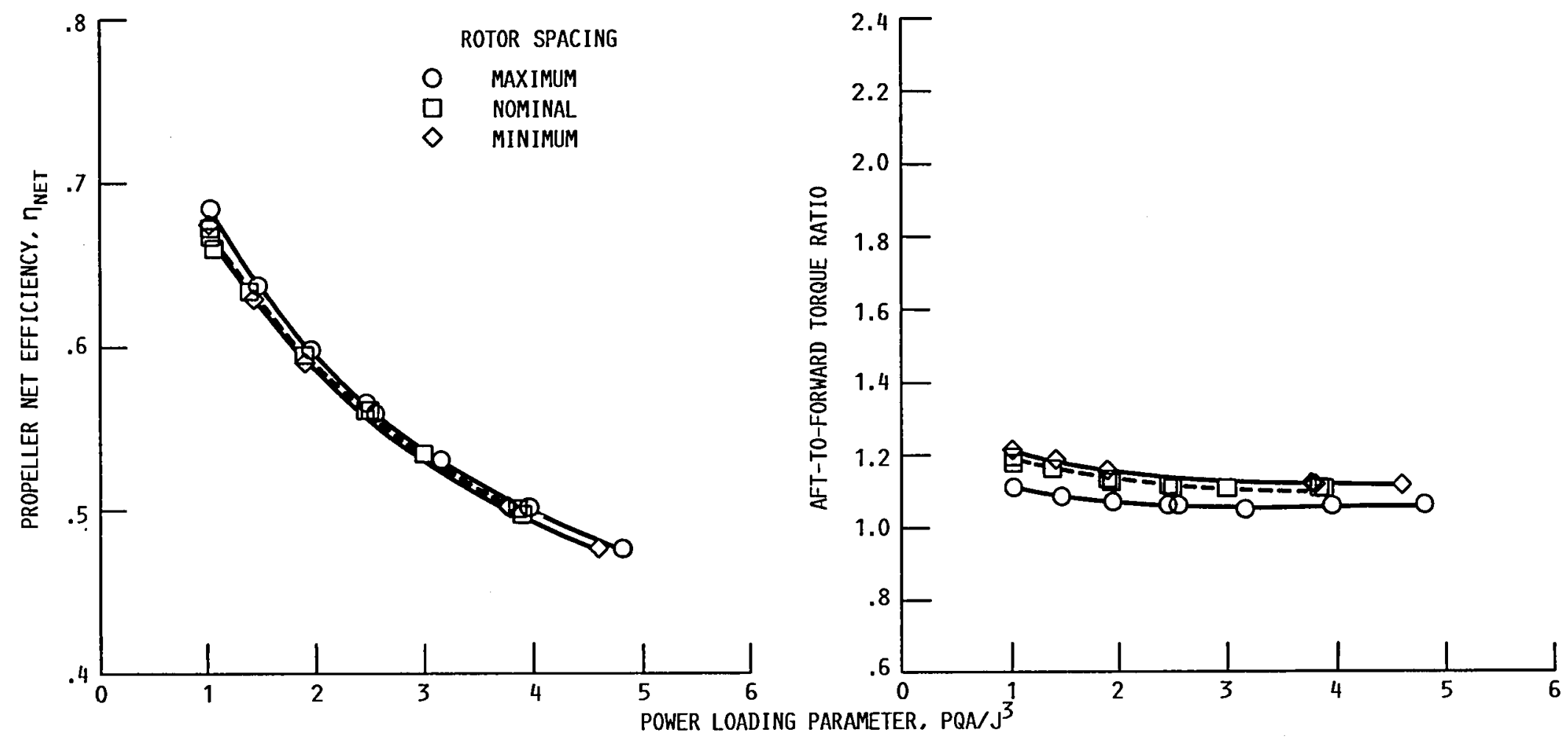

(a) PROPELLER NET EFFICIENCY.

(b) AFT-TO-FORWARD TORQUE RATIO.

FIGURE 11. - EFFECT OF AXIAL ROTOR SPACING F7/A3 11/9 PROPELLER PERFORMANCE AT MACH NUMBER 0.20 AND BLADE ANGLES 36.4/43.5 (TAKE-OFF POINT POWER LOADING PARAMETER OF 3.83). 
$\mathbb{\infty}$

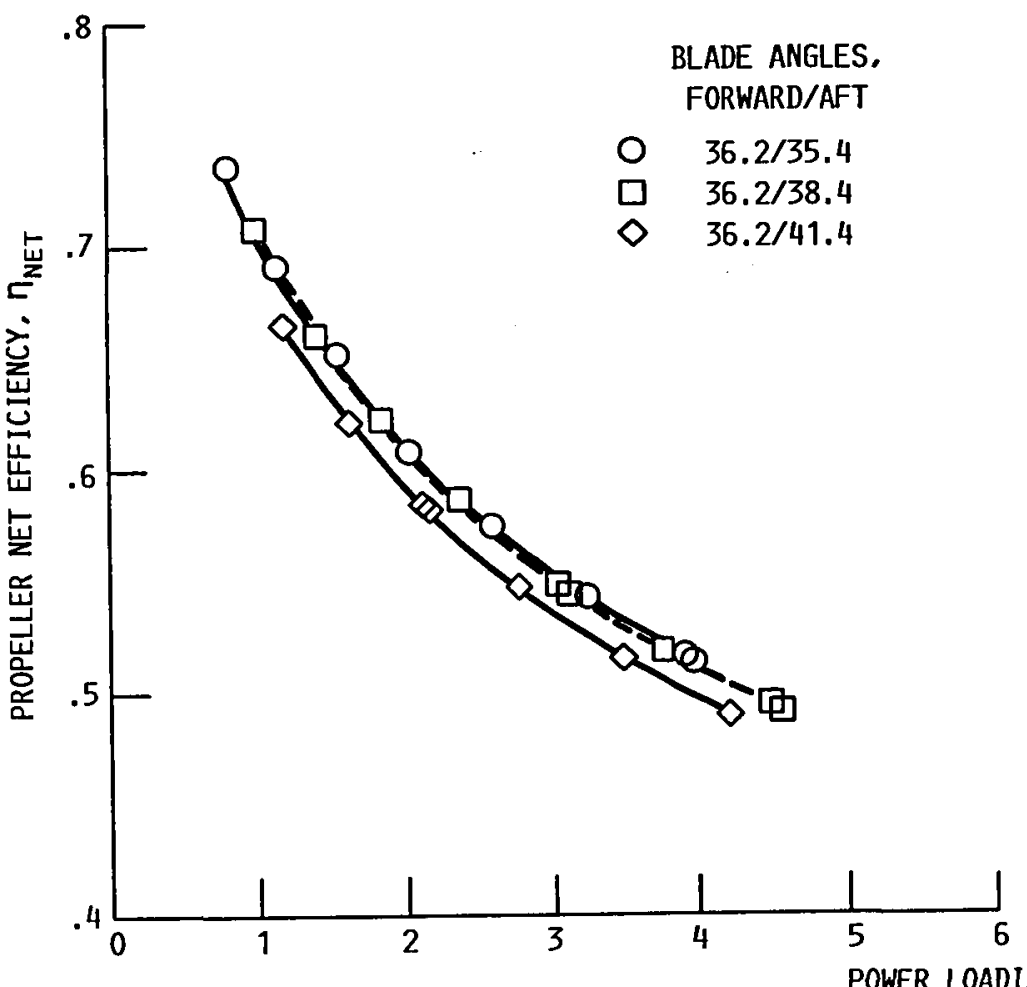

(a) PROPELLER NET EFFICIENCY.

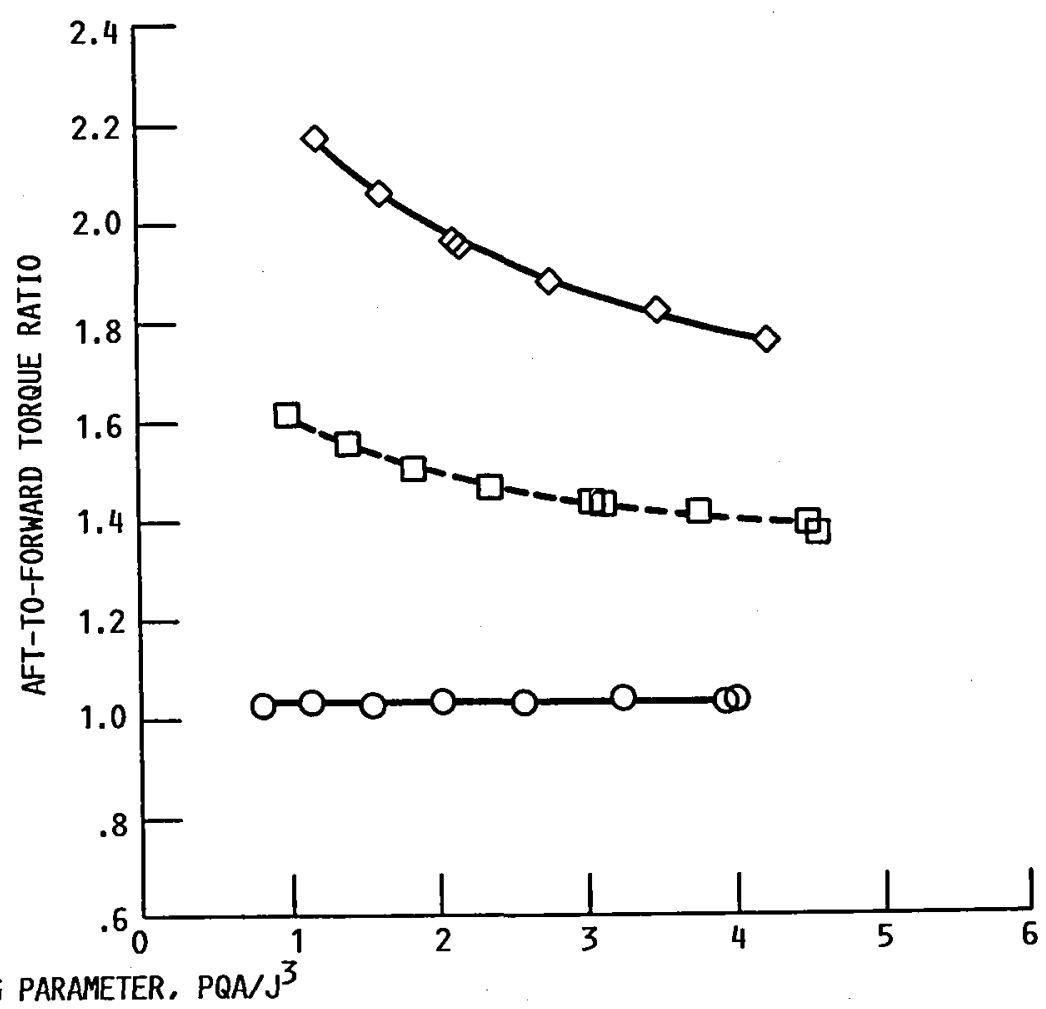

(b) AFT-TO-FORWARD TORQUE RATIO.

FIGURE 12. - EFFECT OF VARYING AFT PROPELLER ROTOR POWER ON F7/A7 8/8 PROPELLER PLRFORMANCE AT MACH NUMBER 0.20 (TAKE-OFF POINT POWER LOADING PARAMETER OF 3.83). 


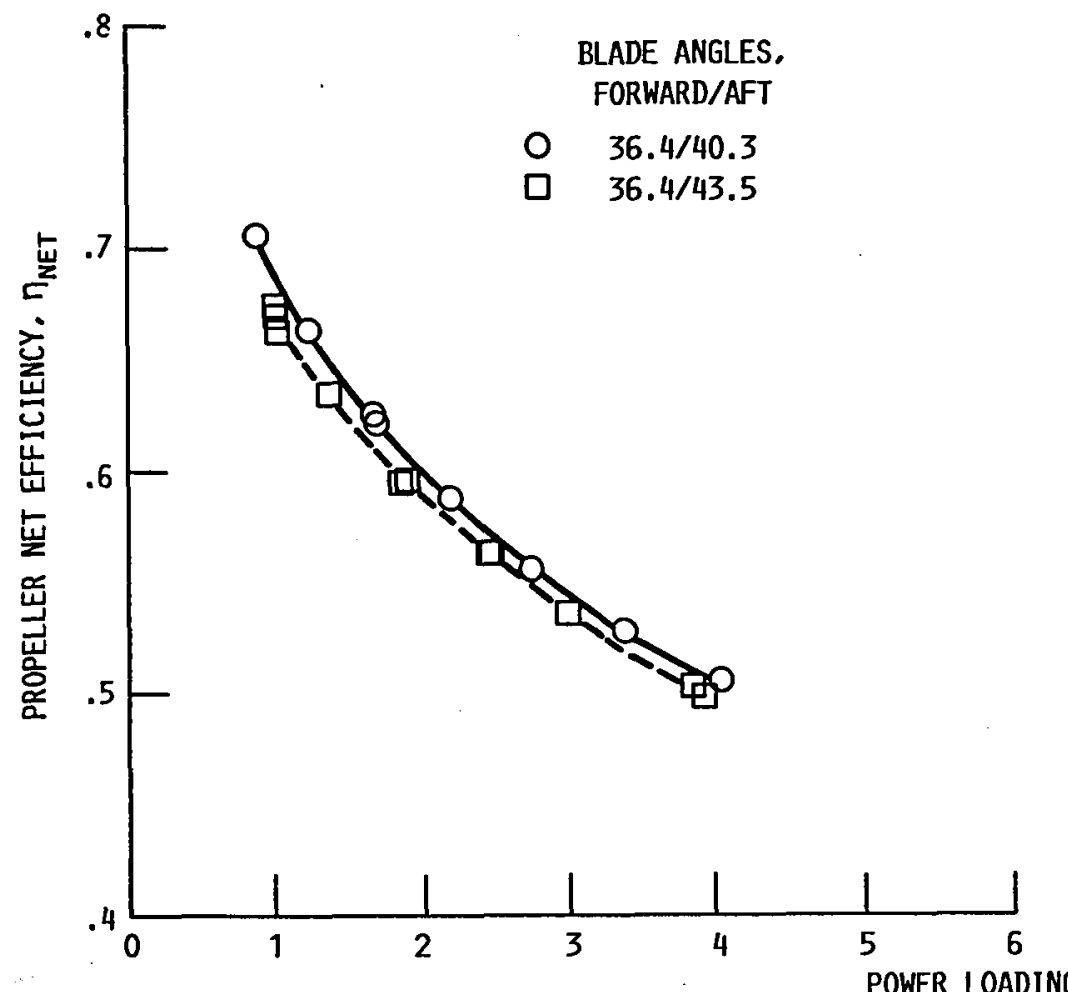

(a) PROPELLER NET EFFICIENCY.

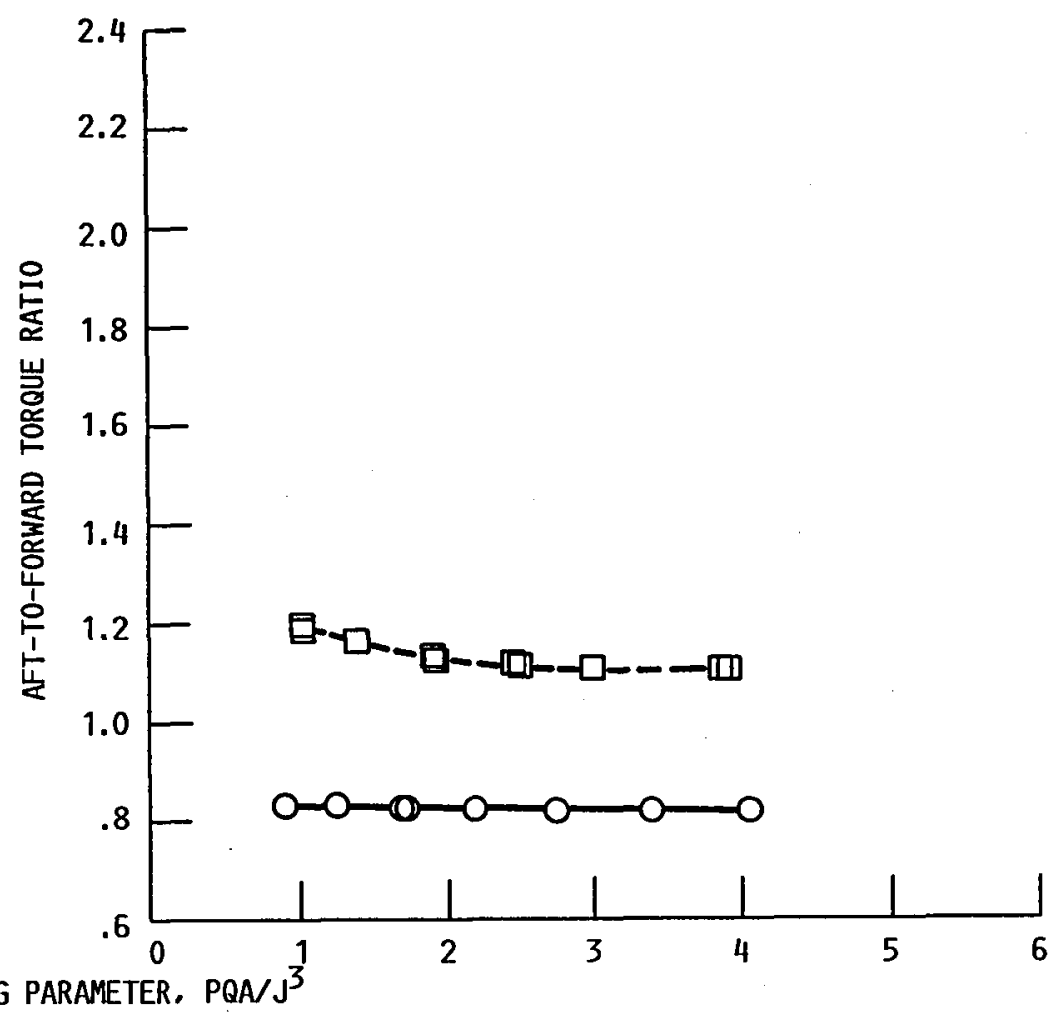

(b) AFT-TO-FORWARD TORQUE RATIO.

FIGURE 13. - EFFECT OF VARYING AFT PROPELLER ROTOR POWER ON F7/A3 11/9 PROPELLER PERFORMANCE AT MACH NUMBER 0.20 (TAKEOFF POINT POWER LOADING PARAMETER OF 3.83 ). 


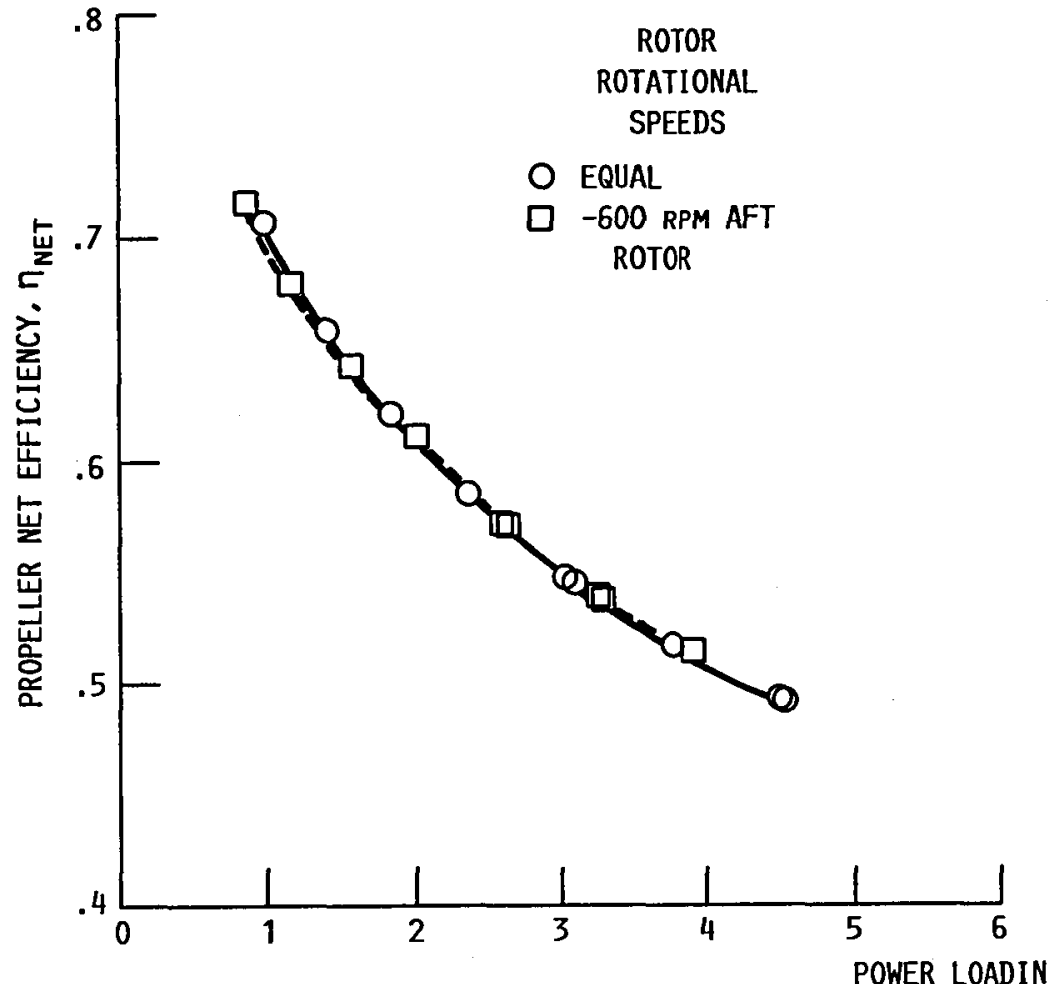

(a) PROPELLER NET EFFICIENCY.

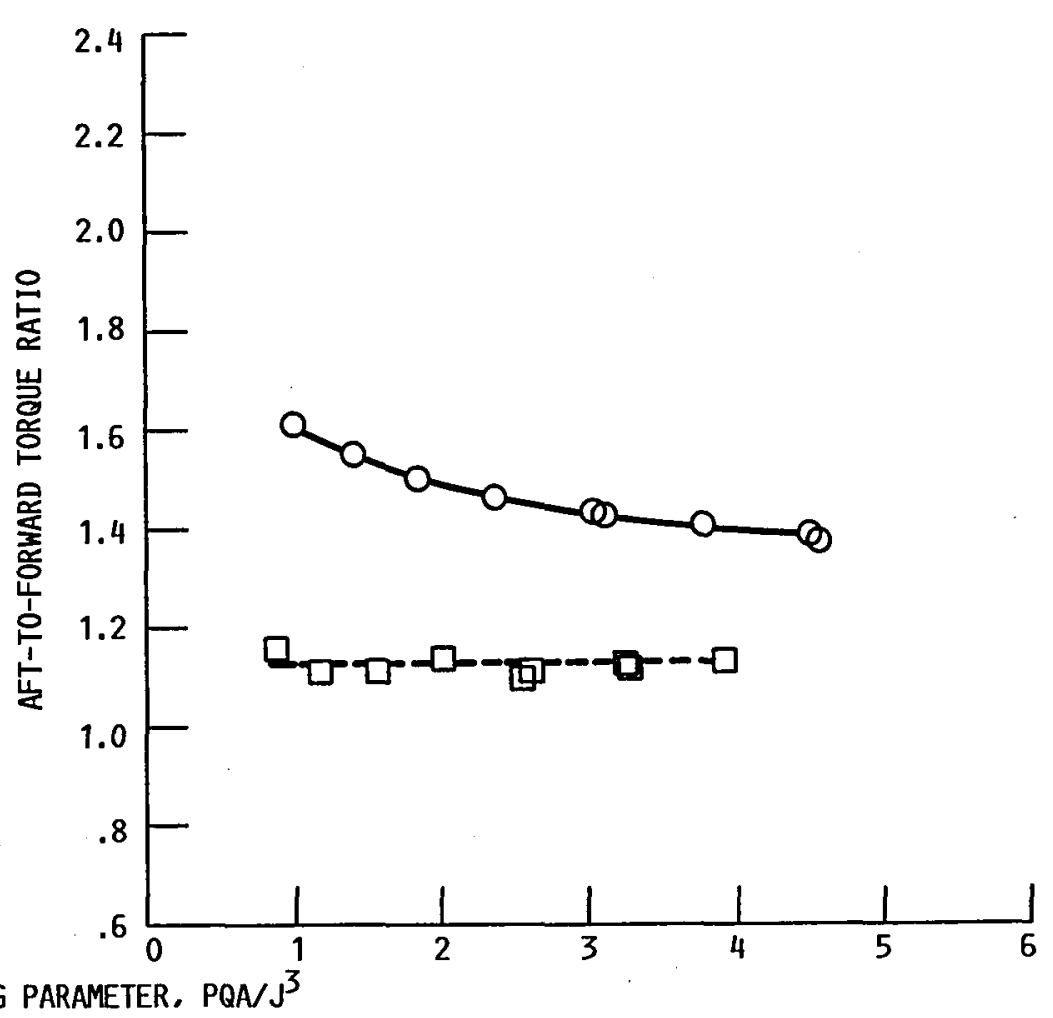

(b) AFT-TO-FORWARD TORQUE RATIO.

FIGURE 14. - EFFECT OF VARYING AFT ROTOR ROTATIONAL SPEED ON F7/A7 8/8 PROPELLER PERFORMANCE AT MACH NUMBER 0.20 AND BLADE ANGLES 36.2/38.4 (TAKE-OFF POINT POWER LOADING PARAMETER OF 3.83). 


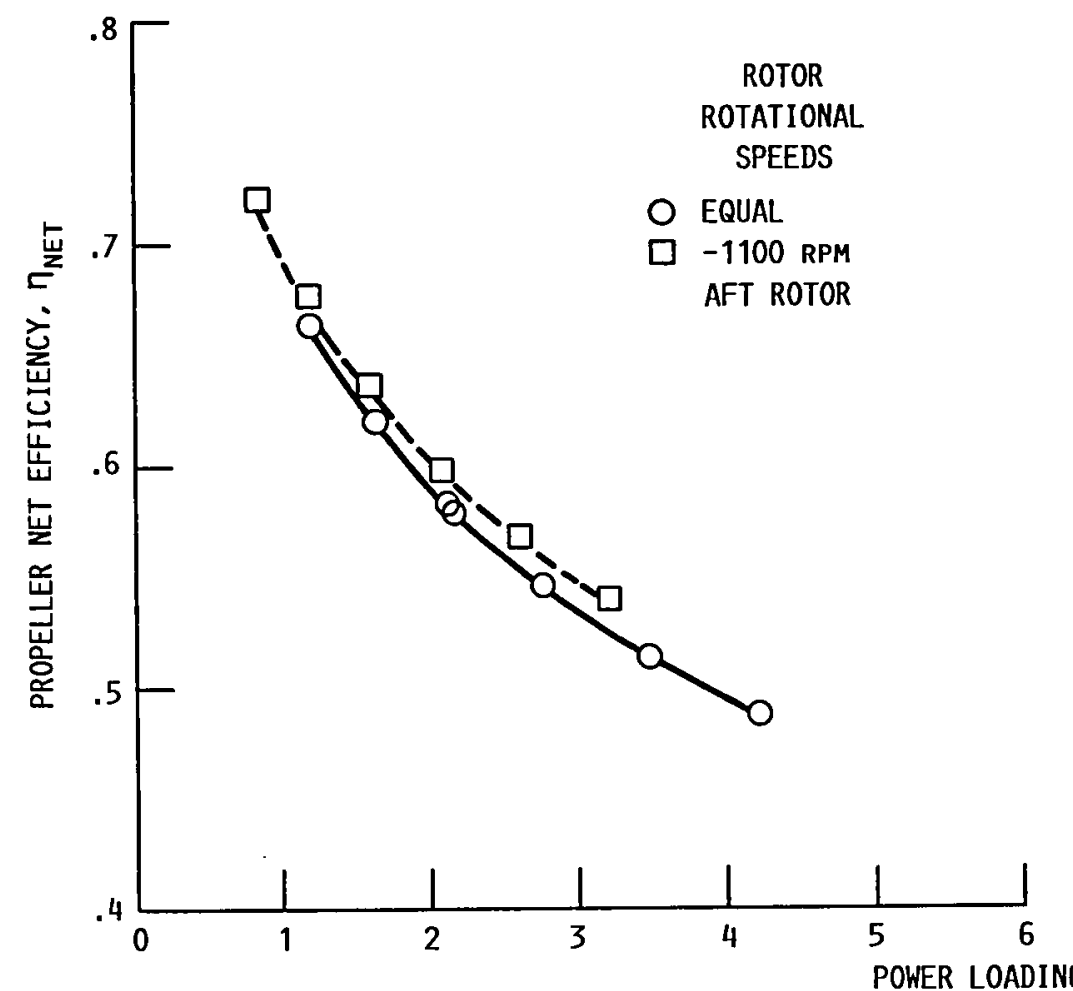

(a) PROPELLER NET EFFICIENCY.

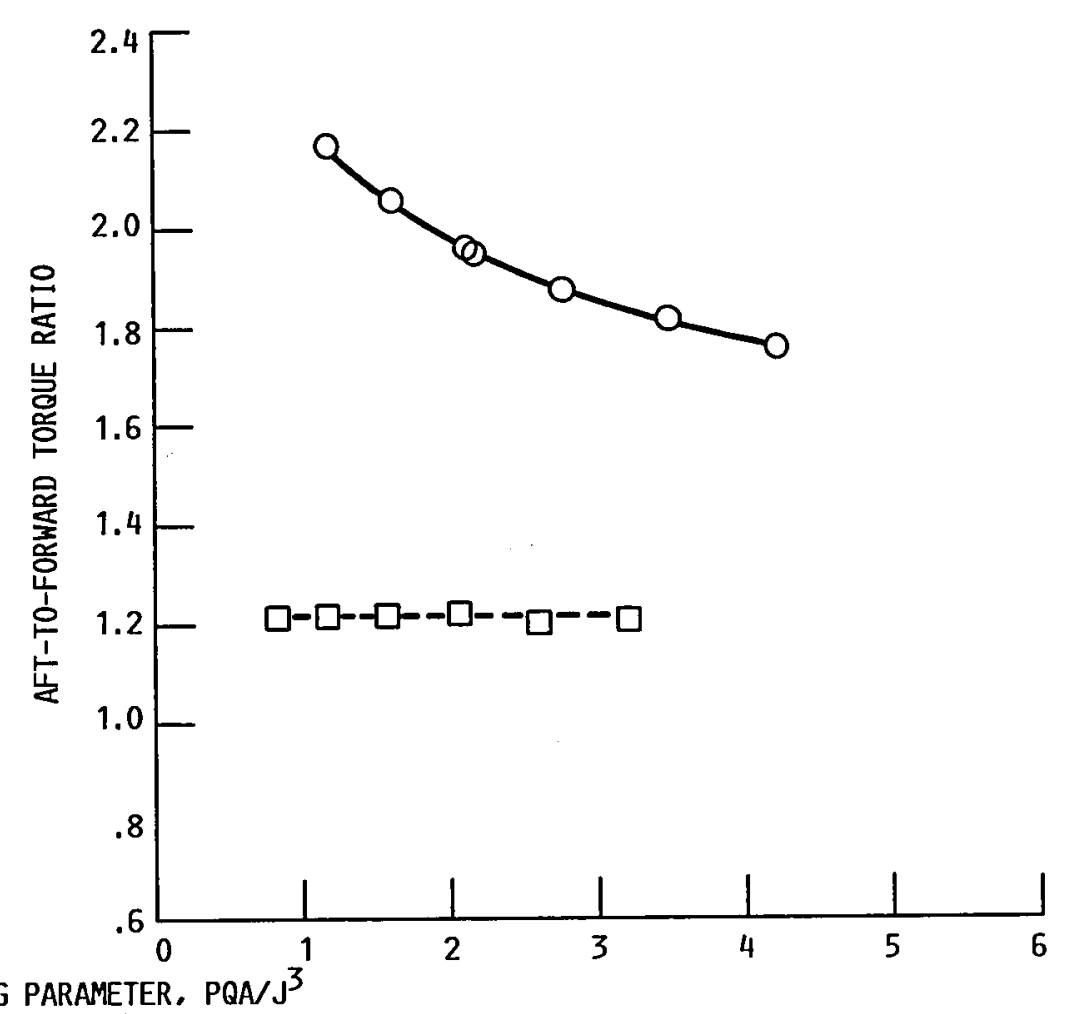

(b) AFT-TO-FORWARD TORQUE RATIO.

FIGURE 15. - EFFECTS OF VARYING AFT ROTOR ROTATIONAL SPEED ON F7/A7 8/8 PROPELLER PERFORMANCE AT MACH NUMBER 0.20 AND BLADE ANGLES 36.2/41.4 (TAKE-OFF POINT POWER LOADING PARAMETER OF 3.83). 


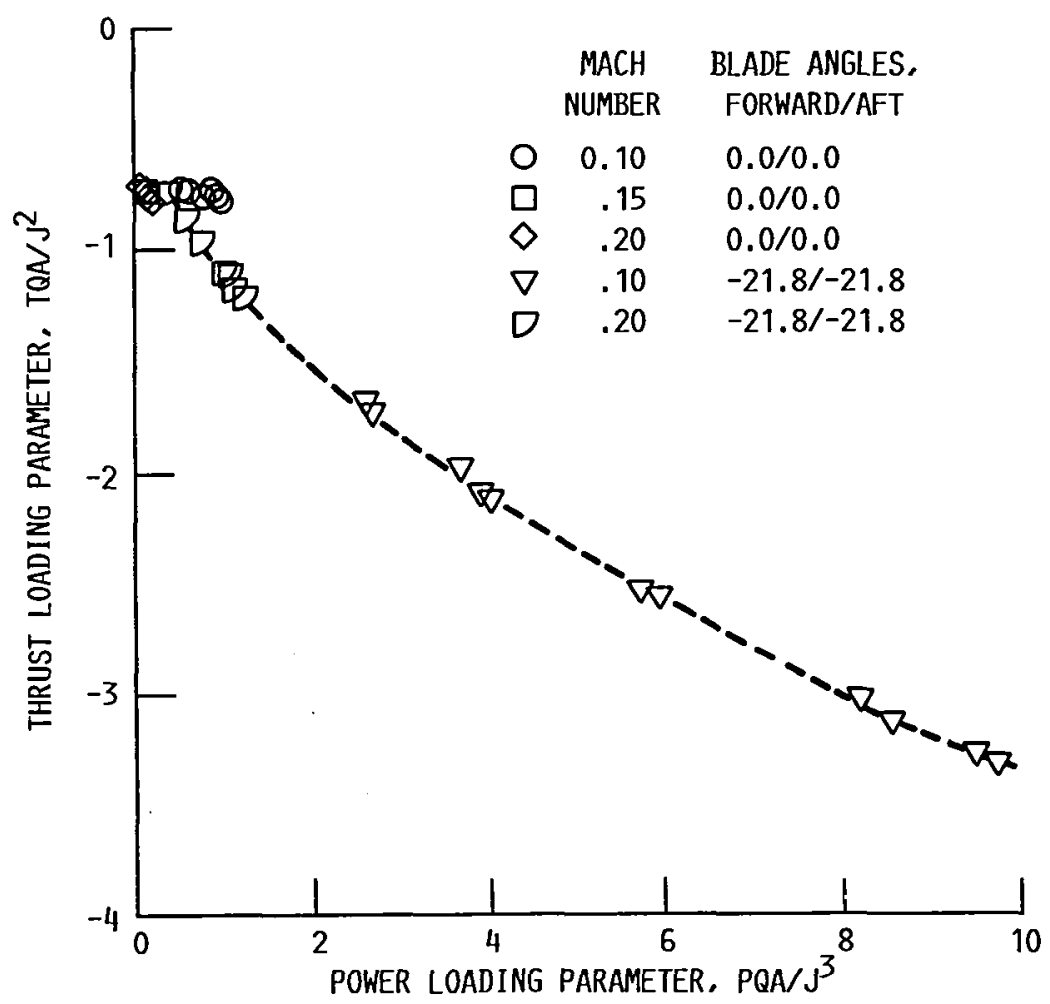

FIGURE 16. - REVERSE THRUST PERFORMANCE OF F7/A7 $8 / 8$ PROPELLER. 


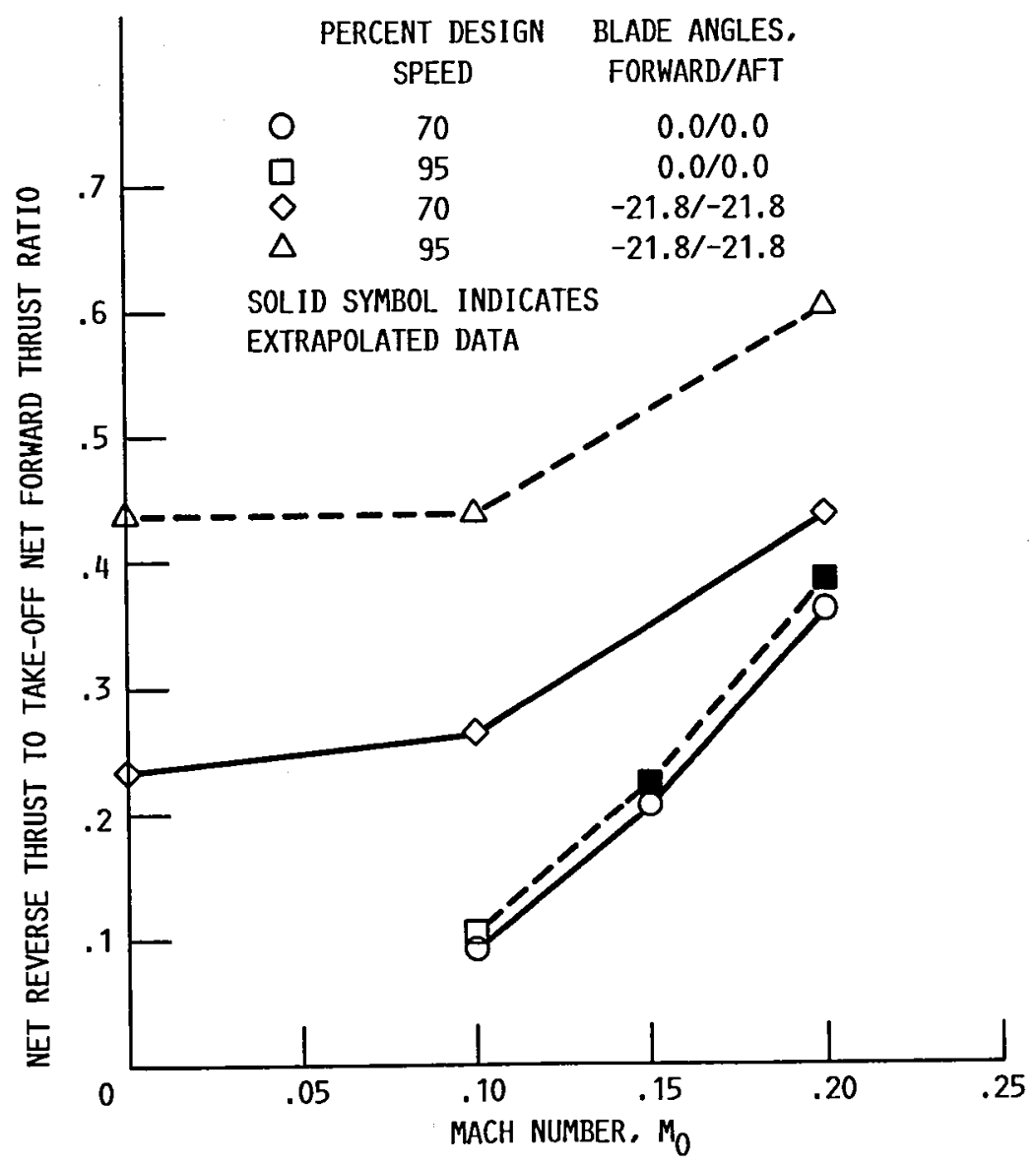

FIGURE 17. - EFFECT OF MACH NUMBER ON REVERSE THRUST PERFORMANCE OF F7/A7 8/8 PROPELLER. 


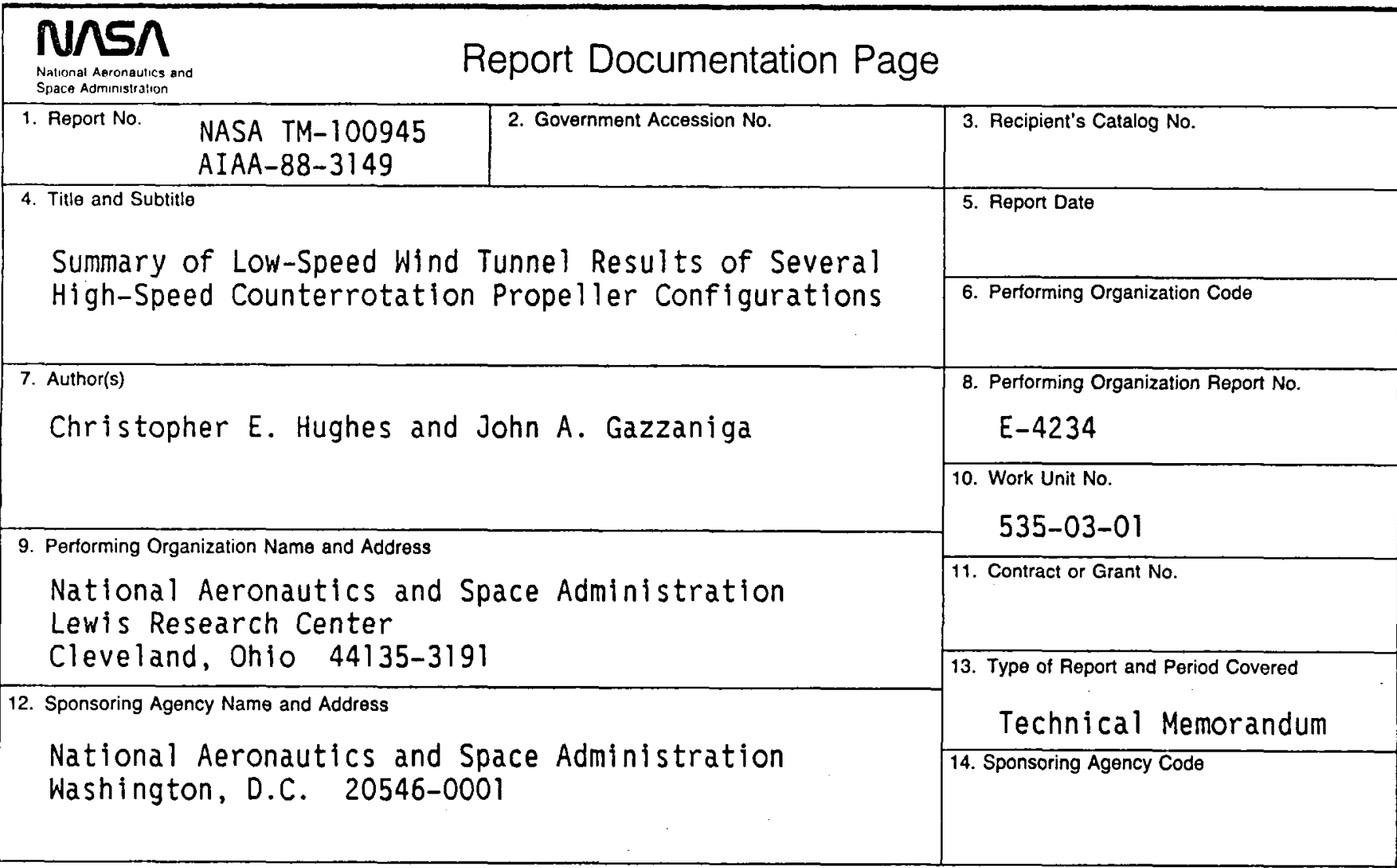

15. Supplementary Notes

Prepared for the 24th Joint Propulsion Conferences cosponsored by the AIAA, ASME, SAE, and ASEE, Boston, Massachusetts, July 11-13, 1988. Christopher E. Hughes, NASA Lewis Research Center; John A. Gazzaniga, Sverdrup Technology, Inc., NASA Lewis Research Center Group, Cleveland, Ohio 44135.

16. Abstract

The low-speed aerodynamic performance characteristics of several advanced counterrotation pusherpropeller configurations with cruise design Mach numbers of 0.72 and 0.80 were investigated in the NASA Lewis Research Center 9- by 15-Foot Low Speed Wind Tunnel. The tests were conducted at Mach numbers representative of the take-off/landing flight regime. The investigation included: (1) the propeller performance characteristics over a range of blade angle settings and rotational speeds at a Mach number of 0.20 ; (2) the effect on the propeller performance of varying the axial rotor spacing and mismatching the power and rotational speeds on the propeller rotors; and (3) determining the reverse thrust performance characteristics at Mach numbers of $0.0,0.10,0.15$, and 0.20 . The results of the investigation indicated that the overall low-speed performance of the counterrotation propelier configurations was reasonable. The maximum propeller net efficiency achieved was 52.4 percent by the F7/A7 $11 / 9$ propeller configuration at a take-off target operating point power loading parameter of 3.83 . The results also indicated that the performance of the propeller configurations was fairly insensitive to changes in axial rotor spacing and mismatched torque on the propeller rotors (resulting from mismatching the power and the rotational speed on the rotors) at a take-off point power loading parameter of 3.83 . By decreasing the axial rotor spacing, the F7/A3 $11 / 9$ propeller configuration showed the largest difference in propeller performance with a 0.7 decrease in net efficiency and a 6.1 percent increase in torque ratio. By mismatching the power on the propeller rotors (by increasing the aft propeller rotor blade angles), the F7/A3 $11 / 9$ configuration had the largest difference in performance with a 0.8 percent decrease in net efficiency and a 28.4 percent increase in torque ratio. By mismatching the rotor rotational speeds 14.8 percent (by reducing the aft rotor rotational speed by 1100 rpm), the increase in F7/A7 8/8 propeller net efficiency was 1.5 percent and a 56.8 percent decrease in torque ratio. At Mach number 0.20 and 95 percent of the propelier design speed, the reverse thrust results indicated that the F7/A7 8/8 configuration produced 60.4 percent of the take-off point net forward thrust (625 $1 \mathrm{~b}$ of force). At Mach number 0.0 (static conditions) and 95 percent design speed, the same propeller configuration produced reverse thrust equal to 43.5 percent of the take-of $f$ net thrust.

17. Key Words (Suggested by Author(s)) Propeller

Aerodynamic efficiency Wind tunne? Counterrotation 
National Aeroniautics end Space Administration

Lewis Research Center

Cleveland, Ohio 44135

Oricial Business

Penality for Prtvate Uso \$\$00
SECOND CLASS MAIL - . -

UESTED

1176013276531

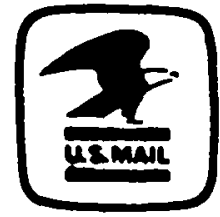

Postage and Fees Paid National Aeronautics and Space Administration NASA-451 